\title{
Dual Pathway Model of Responses Between Climate Change and Livestock Production
}

\author{
Adetunji Oroye lyiola-Tunji, James ljampy Adamu, \\ Paul Apagu John, and Idris Muniru
}

\section{Contents}

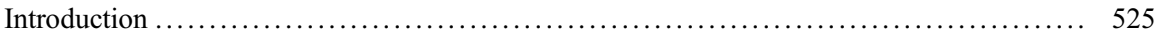

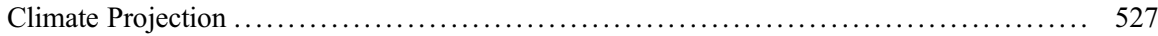

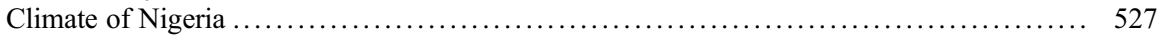

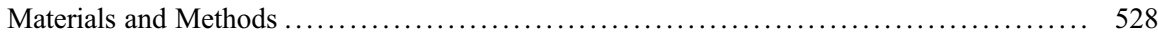

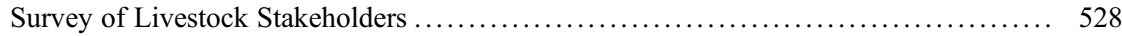

Climate Data and Analysis ................................................ 529

Standardized Precipitation Index and Trend Analysis .......................... 530

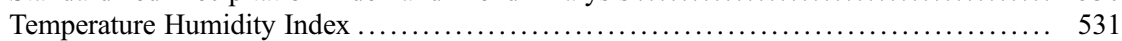



Rainfall Trend/Patterns in Nigeria from 1982 to 2019 ......................... 531

Comparison of Variations in Climatic Elements Among Sahel, Sudan, and Northern Guinea

Savannah Zones ......................................................... 531

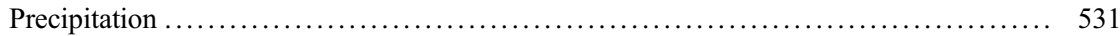

Rainfall Trend/Patterns in Guinea Savannah of Nigeria ....................... 533

This chapter was previously published non-open access with exclusive rights reserved by the Publisher. It has been changed retrospectively to open access under a CC BY 4.0 license and the copyright holder is "The Author(s)". For further details, please see the license information at the end of the chapter.

A. O. Iyiola-Tunji $(\bowtie)$

National Agricultural Extension and Research Liaison Services, Ahmadu Bello University, Zaria, Nigeria

e-mail: tunjiyiola@naerls.gov.ng

J. I. Adamu

Nigerian Meteorological Agency, Abuja, Nigeria

P. A. John

Department of Animal Science, Ahmadu Bello University, Zaria, Nigeria

I. Muniru

Department of Biomedical Engineering, Faculty of Engineering and Technology, University of Ilorin, Ilorin, Nigeria

e-mail: muniru.oi@unilorin.edu.ng

W. Leal Filho et al. (eds.), African Handbook of Climate Change Adaptation, https://doi.org/10.1007/978-3-030-45106-6_230 


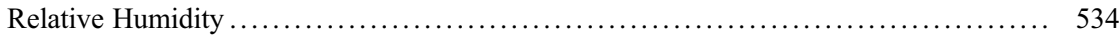

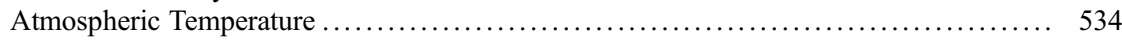

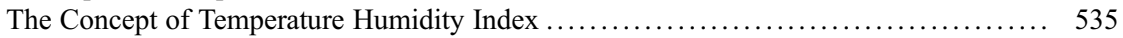

Livestock Production Characteristics in Sahel, Sudan, and Guinea Savannah Zones of

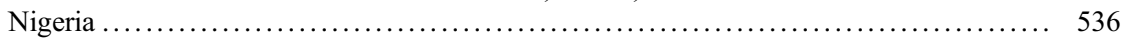

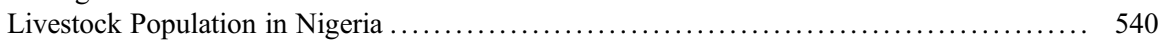

Adaptive Measures Against the Effect of Climate Change on Livestock Production .... . 545

Contribution of Livestock Production Activities Toward Climate Change ............ 547

Adaptive Measures Toward Mitigation of Effect of Climate Change on Livestock ..... . 550

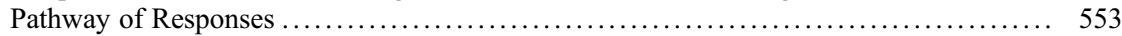

Predicting Climatic Conditions Using Machine Learning Approach ................. 555



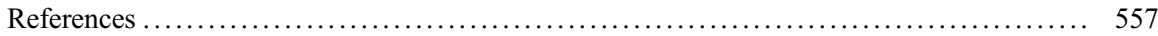

\section{Abstract}

This chapter was aimed at evaluating the responses of livestock to fluctuations in climate and the debilitating effect of livestock production on the environment. Survey of livestock stakeholders (farmers, researchers, marketers, and traders) was carried out in Sahel, Sudan, Northern Guinea Savannah, Southern Guinea Savannah, and Derived Savannah zones of Nigeria. In total, 362 respondents were interviewed between April and June 2020. The distribution of the respondents was 22 in Sahel, 57 in Sudan, 61 in Northern Guinea Savannah, 80 in Southern Guinea Savannah, and 106 in Derived Savannah. The respondents were purposively interviewed based on their engagement in livestock production, research or trading activities. Thirty-eight years' climate data from 1982 to 2019 were obtained from Nigerian Metrological Agency, Abuja. Ilela, Kiyawa, and Sabon Gari were chosen to represent Sahel, Sudan, and Northern Guinea Savannah zone of Nigeria, respectively. The data contained precipitation, relative humidity, and minimum and maximum temperature. The temperature humidity index (THI) was calculated using the formula: $\mathrm{THI}=0.8^{*} \mathrm{~T}+\mathrm{RH}^{*}(\mathrm{~T}$ 14.4) +46.4 , where $\mathrm{T}=$ ambient or dry-bulb temperature in ${ }^{\circ} \mathrm{C}$ and $\mathrm{RH}=$ relative humidity expressed as a proportion. Three Machine Learning model were built to predict the monthly minimum temperature, maximum temperature, and relative humidity respectively based on information from the previous 11 months. The methodology adopted is to treat each prediction task as a supervised learning problem. This involves transforming the time series data into a feature-target dataset using autoregressive (AR) technique. The major component of the activities of livestock that was known to cause injury to the environment as depicted in this chapter was the production of greenhouse gases. From the respondents in this chapter, some adaptive measures were stated as having controlling and mitigating effect at reducing the effect of activities of livestock on the climate and the environment. The environment and climate on the other side of the dual pathway is also known to induce stress on livestock. The concept of crop-livestock integration system is advocated in this chapter as beneficial to livestock and environment in the short and long run. Based on the predictive model developed for temperature and relative humidity in a sample location (Ilela) using Machine 
Learning in this chapter, there is need for development of a web or standalone application that will be useable by Nigerian farmers, meteorological agencies, and extension organizations as climate fluctuation early warning system. Development of this predictive model needs to be expanded and made functional.

\section{Keywords}

Savannah $\cdot$ Sudano-Sahel $\cdot$ Climate change $\cdot$ Adaptation Livestock $\cdot$ Nigeria

\section{Introduction}

Livestock is important as sources of food (FAO 1993; Murphy and Allen 2003), fiber (Iyiola-Tunji 2012), and farm power (Srivastava 2006; Umar et al. 2013) in most part of sub-Saharan Africa. Adesogan et al. (2020) elaborated on the fact that the almost 800 million people who live in poverty (living on less than $\$ 1.90$ per day) and subsist on a diet heavily based on starchy foods. They elaborated that animal source food will be required for millions more people who are slightly better off in terms of their incomes because animal source food provide not only calories but, more importantly, the nutrients required for achievement of human development potential. The dependability of some livestock keepers transcends the basic uses of the products and byproducts of livestock to their uses as a form of savings for the raining days. Schmidt (2008) argued in favor of wealth storage in the form of cattle as a rational investment decision. Bettencourt et al. (2015) presented livestock feature as living savings which can be converted into cash whenever its needed, as well as a security asset influencing access to informal credits and loans and being also a source of collateral for loans.

It is expected that as the population of humans is increasing, the demands for animal products will also be increasing (FAO 2011). However, the production environments from which most of our animals are coming from in Africa are not improving commensurately to the potential demands for the stocks. The breeds of animals that are indigenous to specific locations in Africa have the advantages of adaptability to the environment from which they have lived for several hundreds of years. The environments to which these animals are adapted are heavily laden with stress. This in turn leads to low productivities. Heat stress is an intriguing factor that negatively influences livestock production and reproduction performances (Berihulay et al. 2019).

The dynamics of the environment in sub-Saharan Africa is widely varied within and between regions. In Nigeria, there are humid forest in the South and different categories of Savannah Northward. According to Abdulkadir et al. (2015), the potential impact of climate change, rainfall variability patterns and the dynamic hydrologic regimes have continued to escalate land degradation and make it imperative that the broad ecoclimatic zones could have changed. Variability of climate elements can also predispose animals to diseases. The distribution and incidence of animal diseases, specifically vector borne disease, are directly influenced by climate 
because the geographical distributions of vectors are predetermined by temperature and humidity (Kebede et al. 2018). Livestock production is being adversely affected by detrimental effects of extreme climatic conditions. Consequently, adaptation and mitigation of detrimental effects of extreme climates have played a major role in combating the climatic impact in livestock production (Khalifa 2003).

The level of aridity increases northward in the country. Haider (2019) reported on the challenges associated with climate change in Nigeria which are not the same across the country. The low precipitation in the North and high precipitation in parts of the South were reported to have led to aridity, drought, and desertification in the North and erosion due to flooding in the South (Onah et al. 2016; Akande et al. 2017). The more arid zones are the regions with the most population of livestock like cattle, sheep, and goats. Animals like camel and donkeys are exclusively found in the most arid regions of the country also. Over the years there had been reported cases of extreme high temperatures, drought, flooding, and some other climate-induced stressors. These phenomena always result in losses in productivity of the animals and accruable incomes to the farmers. So, in combating these problems, farmers (especially pastoralists) had adopted migration southward with their animals during the dry season when feed resources and water are not readily available. Some more adaptive measures along with the seasonal migration of stocks were evaluated in this chapter.

Apart from the effect of climate change on livestock which had been studied extensively, animals on higher production levels tend to be more sensitive to high temperature and humidity (Hahn 1989; Aydinalp and Cresser 2008; Nwosu and Ogbu 2011), there is also need for the understanding of the effect of livestock production activities that are capable of causing changes in climatic elements. Based on the submission of Brown (2019) and FAO report (http://www.fao.org/ news/story/en/item/197623/icode/), rearing livestock generates $14.5 \%$ of global greenhouse gas emissions that are very bad for the environment. Livestock and their by-products account for million tons of carbon dioxide per year (Flachowsky and Kamphues 2012). Extensive system of livestock production plays a critical role in land degradation, climate change, water, and biodiversity loss. The problems surrounding livestock production cannot be considered in isolation. Economic, social, health, and environmental perspectives will be critical to solving some of these problems. There is need for development of a greater understanding of these complex issues so that we may encourage policies and practices to reduce the adverse effects of livestock production on climate, while ensuring that humans are fed and natural resources are preserved. A Human Society International report advocated that mitigating the animal agriculture sector's significant yet underappreciated role in climate change is vital for the health and sustainability of the planet, the environment, and its human and non-human inhabitants. Reducing greenhouse gasses (GHG) emissions, especially from animal agriculture is both urgent and critical (https://www.humanesociety.org/sites/default/files/docs/hsus-report-agricul ture-global-warming-and-climate-change.pdf). This chapter however was aimed at evaluating the observed effects of fluctuation of climatic elements on livestock production and vice versa. 


\section{Climate Projection}

The climate of the future is not clear due to how factors such as socioeconomics, technology, land use, and emissions of greenhouse gases will change and unfold (van Vuuren et al. 2011). A climate change scenario represents a specific possible future climate with for example high amounts of green technology contra a scenario with low amount of green technology. The dominant climate change scenarios are the representative concentration pathways (RCP) family of climate change scenarios. There exist mainly four RCP scenarios which are the RCP2.6, 4.5, 6, and 8.5. The two latter numbers indicate the radiative forcing target level for the year 2100 given a specific timeline, where the radiative forcing is the net change in the energy balance of the earth system due to some forcing agent expressed in watt per square meters $\left(\mathrm{W} / \mathrm{m}^{2}\right)$ (Myhre et al. 2013; van Vuuren et al. 2011). These radiative forcers can be anthropogenic or natural, which can be greenhouse gas emissions or volcanic eruptions, respectively (Myhre et al. 2013).

The RCP2.6 trajectory signifies immediate anthropogenic intervention with strong climate change mitigation (van Vuuren et al. 2011). The RCP4.5 trajectory signifies stabilization of greenhouse gas emissions which like the RCP2.6 is also a scenario containing anthropogenic climate change mitigation but as prolific (Thomson et al. 2011). The RCP6 trajectory is similar to RCP4.5 but where climate change mitigation policies and technology implementations are not as strong (van Vuuren et al. 2011). The RCP8.5 trajectory signifies what is called as the "business as usual" trajectory with an increase in population, slow socioeconomic development, and slow innovation/implementation of technology (Riahi et al. 2011).

A core concept in the discussions around climate change is that of "adaptive capacity" or the potential of a society to adapt with the changes (if any) that might occur in the social ecological system from climate change (IPCC 2007a, b; McClanahan et al. 2008). Changes in climate have the potential to affect the agricultural industry which in turn can affect economic investment and population movements in countries. The livelihoods of many people, notably the poor and vulnerable, could be threatened if government and resource managers are not prepared for even the modest changes associated with climate change (Downing et al. 1997).

\section{Climate of Nigeria}

The climate of Nigeria is dominated by the influence of three main wind currents: the Tropical Maritime (TM) air mass, the Tropical Continental (TC) air mass, and the Equatorial Easterlies (EE) (Ojo 1977). The TM and TC air masses meet along the Inter-Tropical Discontinuity (ITD), which is a key driver of Nigeria's climate. The position of the ITD and oscillation during the year affects the spatial and temporal distribution of key climate characteristics of the country (Adegoke and Lamptey 1999). Following the annual movement of the ITD across the Equator, the rainfall season over Nigeria advances from the coast to the inland areas from March to 
August and retreats from September to November, with a pronounced dry period between December and February. The rainfall patterns in Nigeria show the southern parts of the country with annual rainfall over $3000 \mathrm{~mm}$ and semiarid conditions in the north with annual rainfall less than $500 \mathrm{~mm}$.

\section{Materials and Methods}

\section{Survey of Livestock Stakeholders}

A survey of livestock stakeholders (farmers, researchers, marketers and traders) was carried out in Sahel, Sudan, Northern Guinea Savannah, Southern Guinea Savannah, and Derived Savannah zones of Nigeria (Fig. 1). The regions under these ecoclimatic zones cut across all the 19 States and the Federal Capital Territory (FCT) of Nigeria. In total, 362 respondents were interviewed between April and June 2020. The survey instrument used was designed as an online questionnaire (for literate respondents). The other respondents who cannot fill the online form were administered printed questionnaire for the survey.

The distribution of the respondents was 22 in Sahel, 57 in Sudan, 61 in Northern Guinea Savannah, 80 in Southern Guinea Savannah, and 106 in Derived Savannah (Table 2). The respondents were purposively interviewed based on their engagement in livestock production, research or trading activities. The researchers were sourced

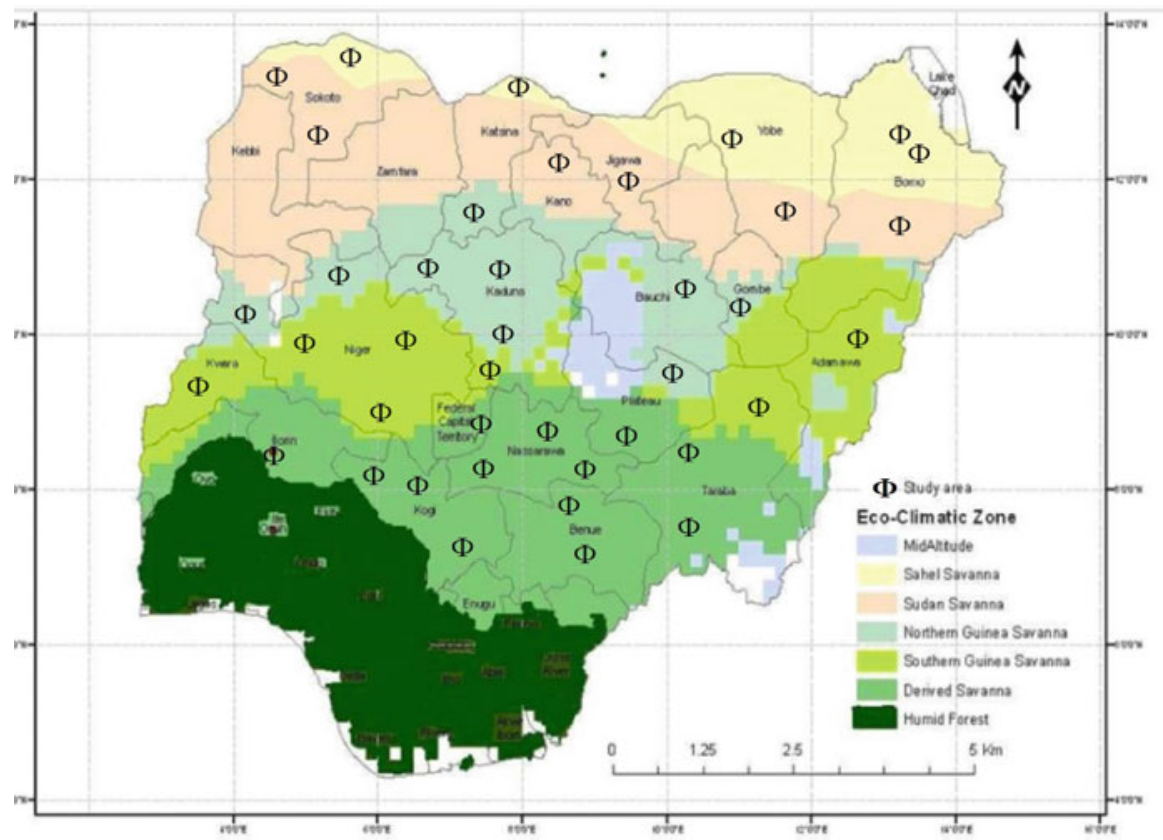

Fig. 1 Ecoclimate zones of Nigeria showing the study areas 
Table 2 Production characteristics of livestock stakeholders in Savannah and Sudano-Sahelian zones of Nigeria $(N=326)$

\begin{tabular}{|c|c|c|}
\hline & Frequency & Percent (\%) \\
\hline \multicolumn{3}{|c|}{ Primary occupation of stakeholders } \\
\hline Livestock farmers & 203 & 62.3 \\
\hline Research scientist & 92 & 28.2 \\
\hline Livestock marketer or trader & 31 & 9.5 \\
\hline \multicolumn{3}{|c|}{ Type of animals being reared by respondents } \\
\hline Cattle & 99 & 30.4 \\
\hline Sheep & 117 & 35.9 \\
\hline Goat & 125 & 38.3 \\
\hline Donkey & 5 & 1.5 \\
\hline Camel & 12 & 3.7 \\
\hline Micro-livestock & 72 & 22.1 \\
\hline Poultry & 144 & 44.2 \\
\hline \multicolumn{3}{|c|}{ Preferred management system as indicated by respondents } \\
\hline Intensive & 163 & 50.0 \\
\hline Semi-intensive & 133 & 40.8 \\
\hline Extensive & 30 & 9.2 \\
\hline \multicolumn{3}{|c|}{ Distribution of respondents according to climate zones } \\
\hline Sahel & 22 & 6.7 \\
\hline Sudan & 57 & 17.5 \\
\hline Northern Guinea Savannah & 61 & 18.7 \\
\hline Southern Guinea Savannah & 80 & 24.5 \\
\hline Derived Savannah & 106 & 32.5 \\
\hline \multicolumn{3}{|c|}{ Awareness of the concept of climate change } \\
\hline Yes & 300 & 92.0 \\
\hline No & 13 & 4.0 \\
\hline Maybe & 13 & 4.0 \\
\hline
\end{tabular}

$\mathrm{N}$ is the number of respondents

through their institutional affiliations. The farmers and marketers were sourced through the Agricultural Development Programs and Ministry of Agriculture (or Livestock) of the 19 States in the Northern regions of Nigeria as well as FCT. Key informant interview was conducted with Alhaji Ibrahim Mohammed - Director, FADAMA and Infrastructural Development of Yobe State Agricultural Development Program, Yobe State. The primary data obtained from this work were analyzed using frequency counts and percentages through crosstab analysis of Statistical Package for Social Sciences (SPSS) Version 16.

\section{Climate Data and Analysis}

Representative locations were chosen for Sahel, Sudan, and Northern Guinea Savannah. Ilela, Kiyawa, and Sabon Gari were chosen to represent Sahel, Sudan, and northern Guinea Savannah zone of Nigeria, respectively. Thirty-eight years' 
climate data from 1982 to 2019 were obtained from Nigerian Metrological Agency, Abuja. The data contained precipitation, relative humidity, and minimum and maximum temperature. This chapter employed the use of grid data obtained from the US National Oceanic and Atmospheric Authority (NOAA) reanalyzed historic data and complimented with Soil and Water Assessment Tool (SWAT) data. The major climatic parameters used in this chapter are rainfall, relative humidity, and temperature. To understand the nature of rainfall variation and trend and to determine climate extremes, data from 1982 to 2019 (38 years) for all weather stations within the study area were used. Descriptive statistical methods such as mean and standard deviation were utilized. Furthermore, time series was used for the analysis of rainfall trend over time, and the Moving Average Technique was also used in the analyses of the data. This chapter employed the use of the 3-Year Moving Average. The moving average has the characteristics of reducing the amount of variation in a set of data. This property in the time series is used mostly to remove fluctuations that are not needed. The use of moving average resulted in the formation of new series in which each of the actual value of the original series is replaced by the mean of itself and some of the values immediately preceding it and directly following it Ayoade (2008). To estimate the value of a variable $\mathrm{Y}$ (i.e., rainfall), corresponding to a given value of a variable $\mathrm{X}$ (i.e., time), regression analysis was applied. This was accomplished by estimating the value of $Y$ from a least-squares curve that fits the sample data.

\section{Standardized Precipitation Index and Trend Analysis}

The Standardized Precipitation Index (SPI) calculation used was based on the longterm precipitation record for the desired period. This long-term record is fitted to a probability distribution, which is then transformed into a normal distribution so that the mean SPI for the location and desired period is zero (Edwards and McKee 1997). Positive SPI values indicate greater than median precipitation, and negative values indicate less than median precipitation. Because the SPI is normalized, wetter and drier climates can be represented in the same way, and wet periods can also be monitored using the SPI.

A correlation was done to determine how well a linear equation describes or explains the relationship between variables. From this analysis, the coefficient of determination was obtained, this is given by $\mathrm{R}^{2}$. The standardized precipitation values were calculated for all the years from the use of the long-term mean, yearly mean, and the standard deviation using the equation below:

$$
\varphi=\frac{X-\bar{X}}{\sigma}
$$

where $\varphi$ represents the standardized departure, $\mathrm{x}$ is the actual value of the parameter (annual rainfall), $\ddot{x}$ is the long term mean value of parameter (30 years rainfall average), and $\sigma$ is the standard deviation. 
Confidence test was performed on the dataset used and it was verified using $95 \%$ confidence interval. Coefficients of skewness, kurtosis, and variation were also investigated.

\section{Temperature Humidity Index}

The temperature humidity index (THI) was calculated using the following formula:

$$
\mathrm{THI}=0.8 * \mathrm{~T}+\mathrm{RH} *(\mathrm{~T}-14.4)+46.4
$$

where $\mathrm{T}=$ ambient or dry-bulb temperature in ${ }^{\circ} \mathrm{C}$ and $\mathrm{RH}=$ relative humidity expressed as a proportion, that is, $75 \%$ humidity is expressed as 0.75 .

\section{Results and Discussion}

\section{Rainfall Trend/Patterns in Nigeria from 1982 to 2019}

The analysis shows the standardized rainfall anomaly over different climatic zones in Nigeria from 1982 to 2019. In the coastal, tropical rainforest, guinea, Sudan savannah areas, it was observed that there are more wet years than dry years. But for the Sahel savannah, the dry years were more than the wet years during the 48 years study period. The result corresponds to IPCC projection stating that the coastal areas are prone to more wet years leading to the occurrence of flooding and rainfall induced erosion, while region around the Sahel will experience more of drought as a result of reduction in the total precipitation.

\section{Comparison of Variations in Climatic Elements Among Sahel, Sudan, and Northern Guinea Savannah Zones}

\section{Precipitation}

Figure 2 showed the weighted average precipitation for Sahel, Sudan, and Northern Guinea Savannah zones of Nigeria. Ilela in Sokoto State was used as a reference point for Sahel while Kiyawa, Jigawa State and Sabon Gari, Kaduna State were used as reference points for Sudan and Northern Guinea Savannah zones, respectively. The number of months with substantial period of precipitation was seven from April to October at Ilela (Sahel). The maximum precipitation $(7.86 \mathrm{~mm})$ was recorded in July. Similar trends of duration of precipitation were also observed at Kiyawa and Sabon Gari. However, the maximum amount of precipitation was 11.97 and $12.31 \mathrm{~mm}$, respectively, for Kiyawa and Sabon Gari. Figure 3 showed the average total precipitation $(\mathrm{mm})$ for Sahel, Sudan, and Northern Guinea Savannah zones of 

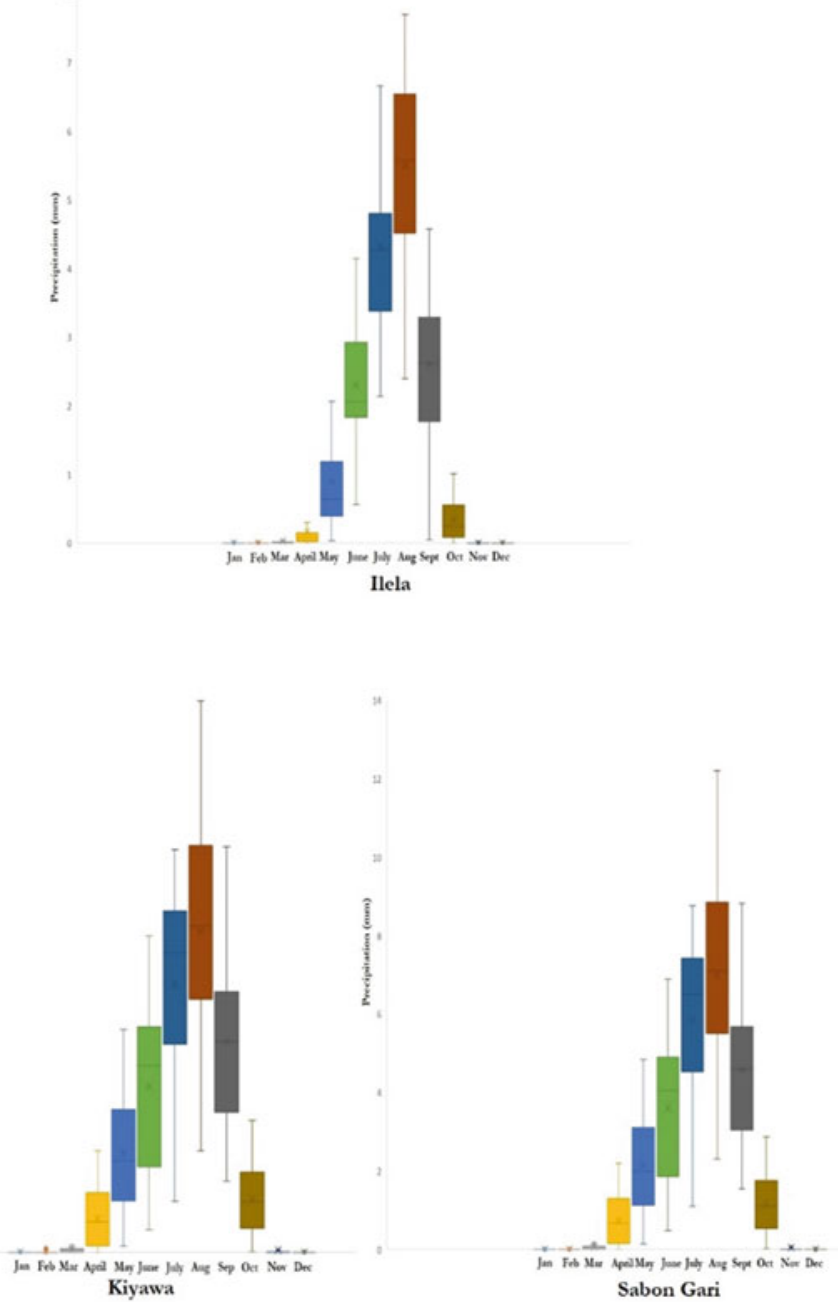

Fig. 2 Weighted average precipitation for Sahel, Sudan, and Northern Guinea Savannah zones of Nigeria for 1982 to 2019

Nigeria from 1982 to 2019 . The average total volume of precipitations within the 38 years for the three zones were $614.79,937.32$, and $958.58 \mathrm{~mm}$, respectively, for the Sahel, Sudan, and Northern Guinea Savannah zones. The volume of precipitation for Sudan and Northern Guinea Savannah were almost similar for most periods of the year except for July, August, and September when the volumes of rainfall was higher in Northern Guinea Savannah zones of Nigeria. The onset and end of rainfall in the two regions were similar.

Analyses of Standardized Precipitation Index (SPI) over the Sahel Savannah of Nigeria are presented in Fig. 5. The figure showed that in the first decade (1971-1980) and the second decade (1981-1990) the whole region had mostly 


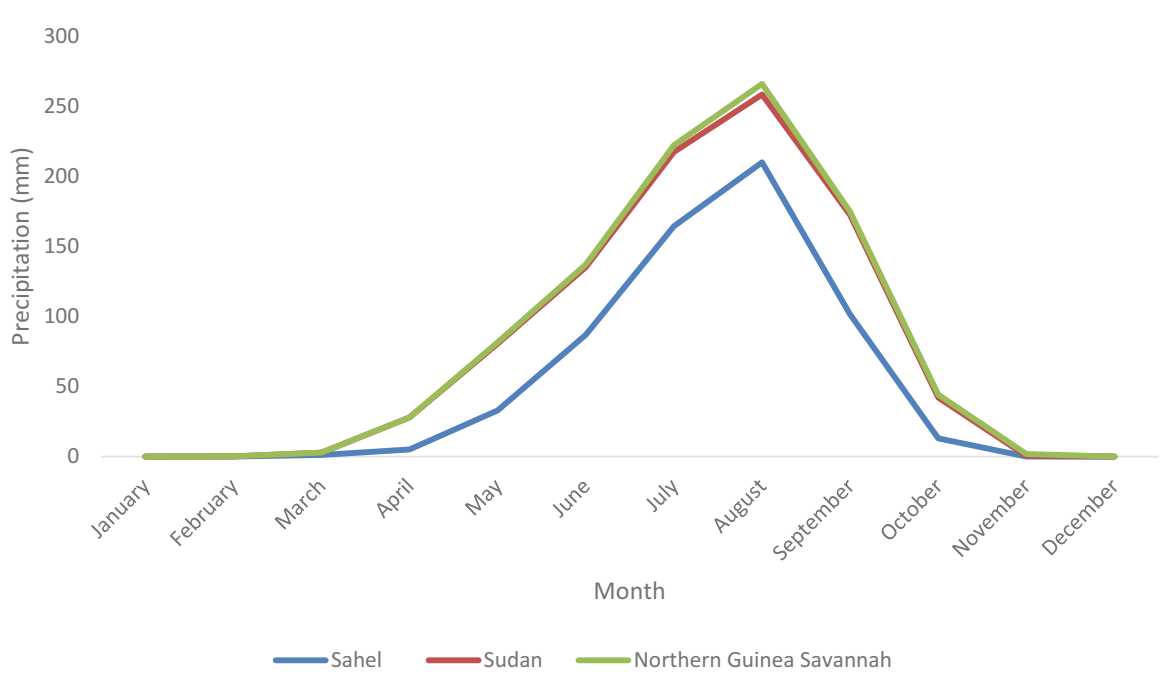

Fig. 3 Average total precipitation ( $\mathrm{mm}$ ) for Sahel, Sudan, and Northern Guinea Savannah zones of Nigeria for 1982 to 2019

negative anomalies. This indicates the zone suffered from serious hydrological drought from 1971 to 1990 . However, there was a recovery to positive anomalies in the third decade (1991-2000), fourth decade (2001-2010), and the current decade (2011-2018). The dry years were more than the wet years during the 48 years study period. The result shows the region recorded 27 dry years and 19 wet years which corresponds to IPCC (2007a) projection stating that the Sahel will experience more of drought as a result of reduction in the total precipitation. With the predominant dry years in the region, water erosion should not have been a problem. Areas affected by water erosion challenges in the region indicates the little rainfall amount recorded occurred at very short interval with high intensity thereby generating runoff. This rainfall pattern is typical under a changing climate.

The analysis shows rainfall trend over Sahel Savannah of Nigeria for 1982-2019 as shown in Fig. 1. From 1981 to 1997 rainfall was increasing and decreasing in cycle of 4-5 years, though the cycle was in a declining rainfall order. During the first decade (1982-1990), the pattern showed decreasing rainfall amount. The second decade (1991-2000) up to 2018 showed a steady increase in rainfall amount a little above the average for region. This trend showed by the moving average for the region is in line with the work of Nicholson and Palao (1993), who reported that rainfall in West Africa generally decreased with latitude with essentially zonal isohyets.

\section{Rainfall Trend/Patterns in Guinea Savannah of Nigeria}

Analyses of Standardized Precipitation Index (SPI) over the Guinea Savannah of Nigeria clearly show that the first decade (1982-1991) had positive anomalies, and in the second decade (1981-1990) the whole region had mostly negative anomalies. 

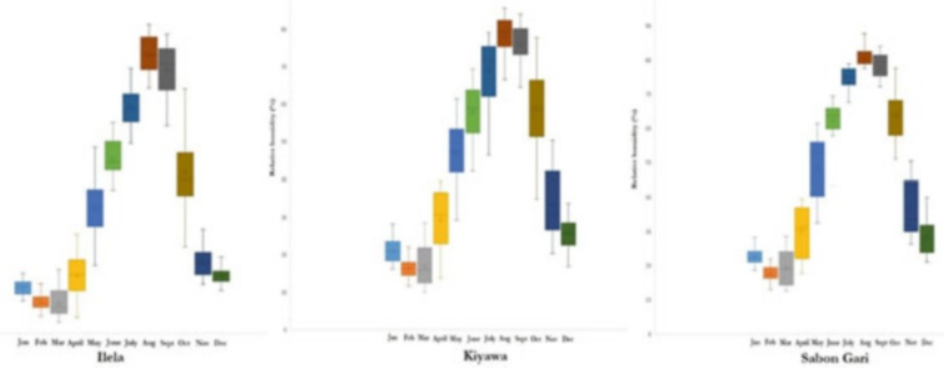

Fig. 4 Weighted average of relative humidity for Sahel, Sudan, and Northern Guinea Savannah zones of Nigeria for 1982 to 2019

However, there was a recovery to positive anomalies in 1991-2000, 2001-2010, and 2011-2018. The dry years were more than the wet years during the 38 years study period. The result shows the region recorded 22 dry years and 15 wet years which corresponds to IPCC projection stating that the region will experience more of wetness as a result of increase in the total precipitation. This is an indication of increased rainfall pattern in the Guinea Savannah region of Nigeria.

Figure 3 shows the rainfall trend over Guinea Savannah of Nigeria for 1971-2018. In the first decade (1971-1980) and the second decade (1981-1990), it was observed that rainfall was below normal (1971-2000) in the region. During the third (1991-2000), fourth (2001-2010), and current decade (2011-2018) it shows a steady increase in rainfall amount in the region above normal. This result is in line with the work of Nicholson and Palao (1993), who reported that rainfall in West Africa generally decreased with latitude with essentially zonal isohyets.

\section{Relative Humidity}

The variations of relative humidity for the zones being considered in this chapter are depicted in Fig. 4. The highest proportions of relative humidity were record in August in the three zones being considered in this chapter. However, the amount of water in the atmosphere was lowest in March of every year across the three regions as shown in Fig. 4. The highest values for relative humidity were $81.11 \%$, $85.55 \%$, and $88.06 \%$ in Sahel, Sudan, and Northern Guinea savannah zones, respectively. The lowest value also follows similar trend of decreasing northward the zones with $7.77 \%, 10.09 \%$, and $12.53 \%$, respectively, for Sahel, Sudan, and Northern Guinea savannah zones.

\section{Atmospheric Temperature}

Figures 5 and 6 show the minimum and maximum temperature in the Sahel, Sudan, and Northern Guinea Savannah zones of Nigeria as represented by Ilela, Kiyawa, and Sabon Gari. The highest value for minimum temperature was observed in May 



Fig. 5: Weighted average of minimum temperature for Sahel, Sudan, and Northern Guinea Savannah zones of Nigeria for 1982 to 2019

and the coldest temperature was in January. While the coldest temperature at Ilela, the Sahel climate, is $12.29{ }^{\circ} \mathrm{C}$; the other two climate zones had similar values of $9.34{ }^{\circ} \mathrm{C}$. Ilela had the highest value for the minimum temperature which was $28.76^{\circ}$ $\mathrm{C}$ which was followed by $26.55^{\circ} \mathrm{C}$ recorded for Sabon Gari and the least among the three climate zones was $25.19^{\circ} \mathrm{C}$ recorded by Kiyawa. The hottest average temperature recorded in all the three zones for the period under consideration in this chapter was $42.55^{\circ} \mathrm{C}$ which was recorded at Ilela in the Sahel climate.

\section{The Concept of Temperature Humidity Index}

Figures 7 and 8 show the temperature humidity index as calculated using minimum and maximum temperatures, respectively. Animals, especially cattle, start having mild stress from index of 72 to 78 . Severe stress starts from 79 to 88 (Table 1). Using the minimum temperatures as reference, the animals in Sahel ecoclimate were mildly 

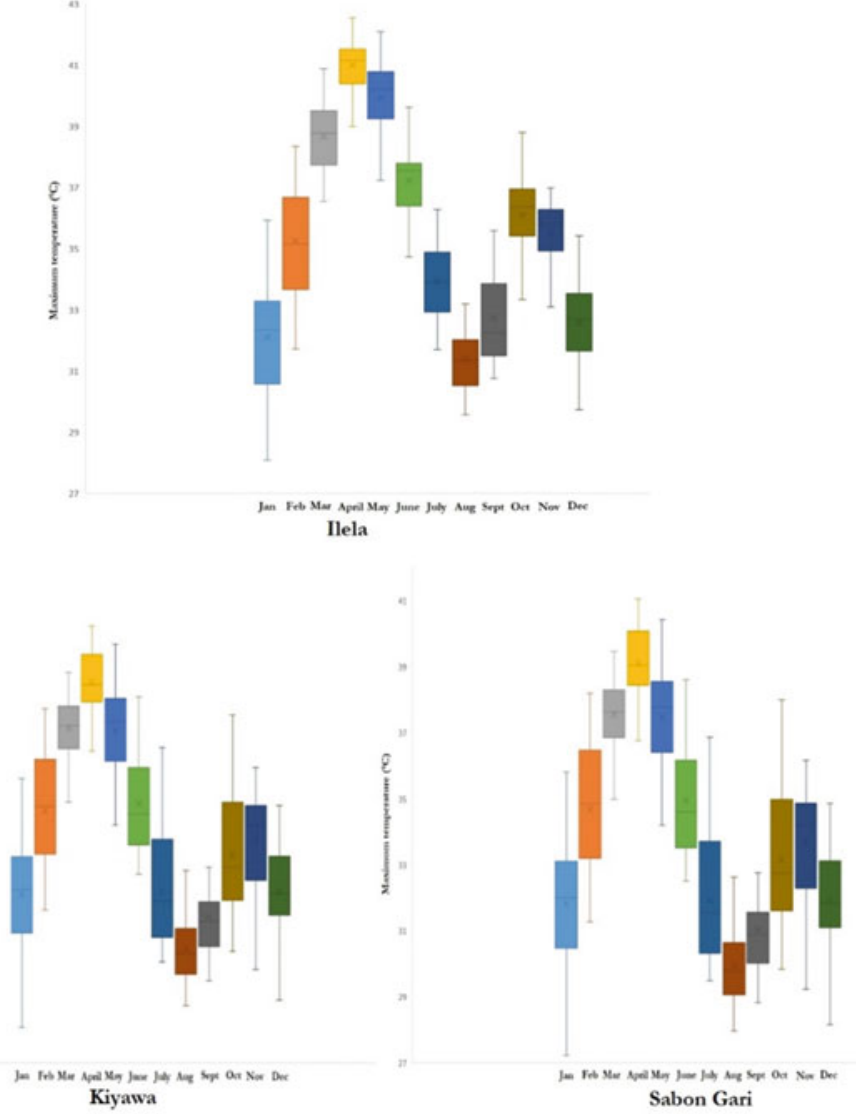

Fig. 6 Weighted average of maximum temperature for Sahel, Sudan, and Northern Guinea Savannah zones of Nigeria for 1982 to 2019

stressed due to heat and relative humidity interactions in May, June, and some days of July. Considering the animals during the maximum temperatures; they were mildly stressed in January, February, and December. That is the period of harmattan in the region. However, the animals are severely stressed for most of the other periods of the year. There were occasions of very severe stress on the animals during some parts of May and June (Fig. 8).

\section{Livestock Production Characteristics in Sahel, Sudan, and Guinea Savannah Zones of Nigeria}

Table 2 shows the production characteristics of livestock stakeholders in the Savannah and Sudano-Sahelian zones of Nigeria. Majority of the respondents were livestock farmers (62.3\%). Substantial proportions of the respondents were research 


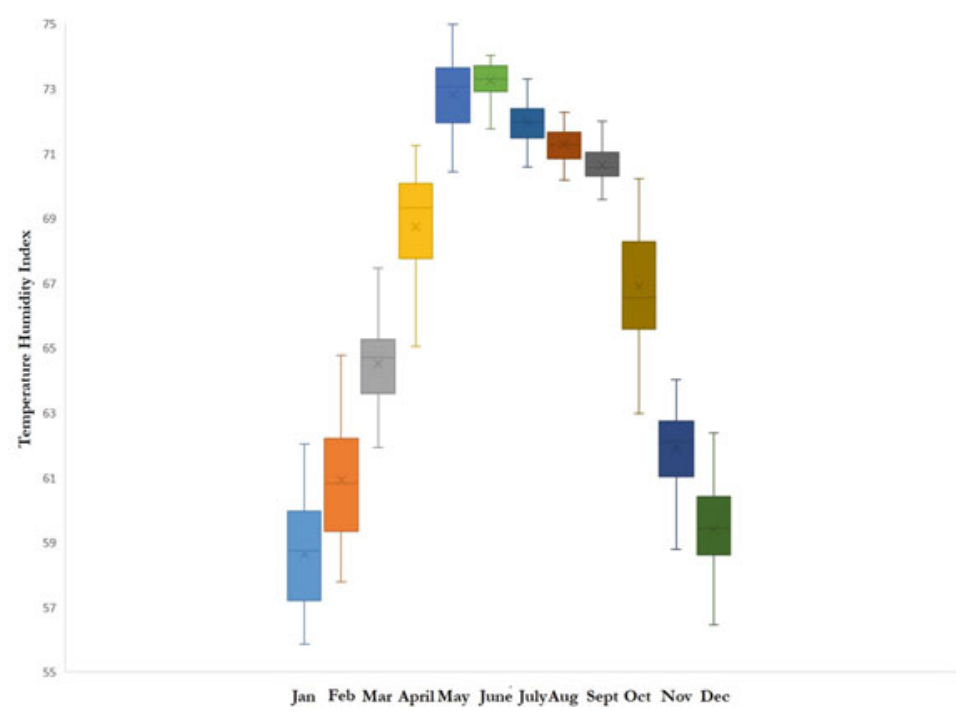

Fig. 7 Temperature humidity index using minimum temperature at Ilela, Sokoto State, as reference point for Sahel ecoclimate zone



Fig. 8 Temperature humidity index using maximum temperature at Ilela, Sokoto State, as reference point for Sahel ecoclimate zone. According to the information in Table 1

scientists $(28.2 \%)$ that are dealing with livestock production in the various agroecological zones covered in this chapter. About $10 \%$ of the respondents were dealing in buying and selling of livestock and poultry. Half the number of the stakeholders interviewed about the interrelationships between climate change and livestock 
Table 1 The temperature humidity index chart

\begin{tabular}{|c|c|c|c|c|c|c|c|c|c|c|c|c|c|c|c|c|c|c|}
\hline \multicolumn{2}{|c|}{ Temp } & \multicolumn{5}{|c|}{ Relative Humidity (\%) } & \multirow[b]{2}{*}{50} & \multirow[b]{2}{*}{55} & \multirow[b]{2}{*}{60} & \multirow[b]{2}{*}{65} & \multirow[b]{2}{*}{70} & \multirow[b]{2}{*}{75} & \multirow[b]{2}{*}{80} & \multirow[b]{2}{*}{85} & \multirow[b]{2}{*}{90} & \multirow[b]{2}{*}{95} & \multirow[b]{2}{*}{100} & \multirow[b]{3}{*}{ MILD } \\
\hline $\mathbf{F}$ & $\mathbf{C}$ & 25 & 30 & 35 & 40 & 45 & & & & & & & & & & & & \\
\hline 77 & 25.0 & & \multirow{3}{*}{\multicolumn{2}{|c|}{ NO STRESS }} & & & 72 & 72 & 73 & 73 & 74 & 74 & 75 & 75 & 76 & 76 & 77 & \\
\hline 78 & 25.6 & & & & & 72 & 73 & 73 & 74 & 74 & 75 & 75 & 76 & 76 & 77 & 77 & 77 & STRESS \\
\hline 79 & 26.1 & & & & 72 & 76 & 73 & 74 & 74 & 75 & 76 & 76 & 77 & 77 & 78 & 78 & 79 & \\
\hline 80 & 26.7 & & 72 & 72 & 73 & 76 & 74 & 74 & 75 & 76 & 76 & 77 & 78 & 78 & 79 & 79 & 80 & \\
\hline 81 & 27.2 & 72 & 72 & 73 & 73 & 74 & 75 & 75 & 76 & 77 & 77 & 78 & 78 & 79 & 80 & 80 & 81 & \\
\hline 82 & 27.8 & 72 & 73 & 73 & 74 & 75 & 75 & 76 & 77 & 77 & 78 & 79 & 79 & 80 & 81 & 81 & 82 & \\
\hline 83 & 28.3 & 73 & 73 & 74 & 74 & 75 & 76 & 77 & 78 & 78 & 79 & 80 & 80 & 81 & 82 & 82 & 83 & SEVERE \\
\hline 84 & 28.9 & 73 & 74 & 75 & 75 & 76 & $n$ & 78 & 78 & 79 & 80 & 80 & 81 & 82 & 83 & 83 & 84 & STRESS \\
\hline 85 & 29.4 & 74 & 75 & 75 & 76 & $n$ & 78 & 79 & 79 & 80 & 81 & 81 & 82 & 83 & 84 & 84 & 85 & \\
\hline 86 & 30.0 & 74 & 75 & 76 & $n$ & 78 & 78 & 79 & 80 & 81 & 81 & 82 & 83 & 84 & 84 & 85 & 86 & \\
\hline 87 & 30.6 & 75 & 76 & 77 & 77 & 78 & 79 & 80 & 81 & 81 & 82 & 83 & 86 & 85 & 85 & 86 & 87 & \\
\hline 88 & 31.1 & 75 & 76 & $n$ & 78 & 79 & 80 & 81 & 81 & 82 & 83 & 84 & 85 & 86 & 86 & 87 & 88 & \\
\hline 89 & 31.7 & 76 & 77 & 78 & 79 & 80 & 81 & 82 & 83 & 84 & 85 & 86 & 86 & 87 & 88 & 89 & 89 & \\
\hline 90 & 32.2 & $n$ & 78 & 79 & 79 & 80 & 81 & 82 & 83 & 84 & 85 & 86 & 86 & 87 & 88 & 89 & 90 & \\
\hline 91 & 32.8 & 77 & 78 & 79 & 80 & 81 & 82 & 83 & 84 & 85 & 86 & 86 & 87 & 88 & 89 & 90 & 91 & \\
\hline 92 & 33.3 & 78 & 79 & 80 & 81 & 82 & 83 & 84 & 85 & 85 & 86 & 87 & 88 & 89 & 90 & 91 & 92 & \\
\hline 93 & 33.9 & 79 & 80 & 80 & 81 & 82 & 83 & 84 & 85 & 86 & 87 & 88 & 89 & 90 & 91 & 92 & 93 & VERY \\
\hline 94 & 34.4 & 79 & 80 & 81 & 82 & 83 & 84 & 85 & 86 & 87 & 88 & 89 & 90 & 91 & 92 & 93 & 94 & SEVERE \\
\hline 95 & 35.0 & 80 & 81 & 82 & 83 & 84 & 85 & 86 & 87 & 88 & 89 & 90 & 91 & 92 & 93 & 94 & 95 & STRESS \\
\hline 96 & 35.6 & 80 & 81 & 82 & 83 & 85 & 86 & 87 & 88 & 89 & 90 & 91 & 92 & 93 & 94 & 95 & 96 & \\
\hline 97 & 36.1 & 81 & 82 & 83 & 84 & 85 & 86 & 87 & 88 & 89 & 91 & 92 & 93 & 94 & 95 & 96 & 97 & \\
\hline 98 & 36.7 & 82 & 83 & 84 & 85 & 86 & 87 & 88 & 89 & 90 & 91 & 93 & 94 & 95 & 96 & 97 & 98 & \\
\hline 99 & 37.2 & 82 & 83 & 84 & 85 & 87 & 88 & 89 & 90 & 91 & 92 & 93 & 94 & 96 & 97 & 98 & 99 & \\
\hline 100 & 37.8 & 83 & 84 & 85 & 86 & 87 & 88 & 90 & 91 & 92 & 93 & 94 & 95 & 97 & 98 & 99 & 100 & \\
\hline 101 & 38.3 & 83 & 86 & 86 & 87 & 88 & 89 & 90 & 92 & 93 & 96 & 95 & 96 & 97 & 99 & 100 & 101 & \\
\hline 102 & 38.9 & 86 & 85 & 86 & 87 & 89 & 90 & 91 & 92 & 96 & 95 & 96 & 97 & 96 & 99 & 101 & 102 & \\
\hline 103 & 39.4 & 86 & 86 & 87 & 88 & 89 & 91 & 92 & 94 & 95 & 96 & 97 & 98 & 100 & 101 & 102 & 103 & \\
\hline 104 & 40.0 & 85 & 86 & 88 & 88 & 90 & 91 & 93 & 94 & 95 & 96 & 97 & 99 & 100 & 101 & 103 & 104 & \\
\hline 105 & 40.6 & 86 & 87 & 88 & 89 & 91 & 92 & 93 & 96 & 96 & 97 & 98 & 99 & 100 & 101 & 104 & 105 & DEAD \\
\hline 106 & 41.1 & 86 & 88 & 89 & 90 & 91 & 93 & 94 & 95 & 97 & 98 & 99 & 101 & 102 & 103 & 105 & 106 & CATTLE \\
\hline 107 & 41.7 & 87 & 88 & 89 & 91 & 92 & 94 & 95 & 96 & 98 & 99 & 101 & 102 & 103 & 105 & 106 & 107 & \\
\hline 108 & 42.2 & 87 & 89 & 90 & 92 & 93 & 94 & 96 & 97 & 98 & 100 & 101 & 102 & 104 & 105 & 106 & 108 & \\
\hline 109 & 42.8 & 88 & 89 & 91 & 92 & 94 & 95 & 96 & 98 & 99 & 101 & 102 & 103 & 105 & 106 & 107 & 109 & \\
\hline 110 & 43.3 & 88 & 90 & 91 & 92 & 94 & 96 & 97 & 98 & 100 & 101 & 102 & 104 & 105 & 106 & 108 & 110 & \\
\hline 111 & 43.9 & 89 & 91 & 93 & 94 & 95 & 96 & 98 & 99 & 101 & 102 & 103 & 105 & 106 & 107 & 109 & 111 & \\
\hline
\end{tabular}

Source Dr. Frank Wiersma (1990). Department of Agricultural Engineering, University of Arizona, Tucson. Downloaded from http://www.veterinaryhandbook.com.au

production preferred intensive management system of production. This can be explained because more than $40 \%$ of them are into commercial poultry production. Semi-intensive is a system of choice for ruminant animal production and it is preferred by $40.8 \%$ of the stakeholders interviewed in this chapter. Umunna et al. (2014) reported $56.3 \%$ of small ruminant producers rearing their stock through semiintensive system.

The distribution of respondents was also shown in Table 3. The largest proportion of respondents $(32.5 \%)$ was from Derived Savannah zone of Nigeria. This is commensurate to the very large land area of this zone when compared with some of the other zones (Fig. 1). The least population of respondents (6.7\%) was from the Sahel zone. The Sahel zone in Nigeria is found at the uppermost portion of the country. Suleiman (2017) described the Sahel region of Africa as a 3,860-kilometer 
Table 3 Features of Savannah and Sudano-Sahelian zones being experienced by respondents

\begin{tabular}{|c|c|c|c|c|c|c|}
\hline Feature & $\begin{array}{l}\text { Sahel } \\
N=22\end{array}$ & $\begin{array}{l}\text { Sudan } \\
N=57\end{array}$ & $\begin{array}{l}\text { Northern } \\
\text { Guinea } \\
\text { Savannah } \\
N=61\end{array}$ & $\begin{array}{l}\text { Southern } \\
\text { Guinea } \\
\text { Savannah } \\
N=80\end{array}$ & $\begin{array}{l}\text { Derived } \\
\text { Savannah } \\
N=106\end{array}$ & $\begin{array}{l}\text { Total } \\
N=326\end{array}$ \\
\hline $\begin{array}{l}\text { Seasonal } \\
\text { variation in } \\
\text { availability of } \\
\text { natural forage }\end{array}$ & $\begin{array}{l}22 \\
(100.0)\end{array}$ & $\begin{array}{l}57 \\
(100.0)\end{array}$ & $58(95.1)$ & $32(40.0)$ & $48(45.3)$ & $\begin{array}{l}217 \\
(66.6)\end{array}$ \\
\hline $\begin{array}{l}\text { Extreme high } \\
\text { temperatures } \\
\text { during dry season }\end{array}$ & $\begin{array}{l}17 \\
(77.3)\end{array}$ & $\begin{array}{l}38 \\
(66.7)\end{array}$ & $41(67.2)$ & $55(68.8)$ & $57(53.8)$ & $\begin{array}{l}208 \\
(63.8)\end{array}$ \\
\hline $\begin{array}{l}\text { Low temperature } \\
\text { during Harmattan }\end{array}$ & $\begin{array}{l}21 \\
(95.5)\end{array}$ & $\begin{array}{l}46 \\
(80.7)\end{array}$ & $24(39.3)$ & $18(22.5)$ & $18(17.0)$ & $\begin{array}{l}127 \\
(39.0)\end{array}$ \\
\hline Low precipitation & $\begin{array}{l}19 \\
(86.4)\end{array}$ & $\begin{array}{l}39 \\
(68.4)\end{array}$ & $17(27.9)$ & $20(25.0)$ & $23(21.7)$ & $\begin{array}{l}118 \\
(36.2)\end{array}$ \\
\hline $\begin{array}{l}\text { Desert } \\
\text { encroachment }\end{array}$ & $\begin{array}{l}13 \\
(59.1)\end{array}$ & $\begin{array}{l}26 \\
(45.6)\end{array}$ & $13(21.3)$ & $22(27.5)$ & $19(17.9)$ & $\begin{array}{l}93 \\
(28.5)\end{array}$ \\
\hline $\begin{array}{l}\text { Sunshine hours } \\
\text { more than } 12 \\
\text { hours }\end{array}$ & $\begin{array}{l}18 \\
(81.8)\end{array}$ & $\begin{array}{l}42 \\
(73.7)\end{array}$ & $14(23.0)$ & $13(16.3)$ & $5(4.7)$ & $\begin{array}{l}92 \\
(28.2)\end{array}$ \\
\hline $\begin{array}{l}\text { Abundance of } \\
\text { grasses and other } \\
\text { fodder crops }\end{array}$ & $\begin{array}{l}6 \\
(27.3)\end{array}$ & $5(8.8)$ & $16(26.2)$ & $19(23.8)$ & $26(24.5)$ & $\begin{array}{l}72 \\
(22.1)\end{array}$ \\
\hline $\begin{array}{l}\text { Low to moderate } \\
\text { relative humidity }\end{array}$ & $\begin{array}{l}4 \\
(18.2)\end{array}$ & $8(14.0)$ & $11(18.0)$ & $12(15.0)$ & $10(9.4)$ & $\begin{array}{l}45 \\
(13.8)\end{array}$ \\
\hline
\end{tabular}

Factors responsible for large population of livestock in Savannah and Sudano-Sahelian zones of Nigeria

\begin{tabular}{l|l|l|l|l|l|l}
\hline $\begin{array}{l}\text { Abundance of } \\
\text { grasses, legumes } \\
\text { and other fodder } \\
\text { crops }\end{array}$ & $\begin{array}{l}11 \\
(50.0)\end{array}$ & $\begin{array}{l}33 \\
(57.9)\end{array}$ & $36(5.9)$ & $48(60.0)$ & $67(63.2)$ & $\begin{array}{l}195 \\
(59.8)\end{array}$ \\
\hline $\begin{array}{l}\text { Large expanse of } \\
\text { grassland }\end{array}$ & $\begin{array}{l}18 \\
(81.8)\end{array}$ & $\begin{array}{l}22 \\
(38.6)\end{array}$ & $29(47.5)$ & $41(51.3)$ & $43(40.6)$ & $\begin{array}{l}153 \\
(46.9)\end{array}$ \\
\hline $\begin{array}{l}\text { Low infestation } \\
\text { of pathogens } \\
\text { during wet season }\end{array}$ & 6 & $\begin{array}{l}67 \\
(27.3)\end{array}$ & $15(24.6)$ & $32(40.0)$ & $30(28.3)$ & $\begin{array}{l}110 \\
(33.7)\end{array}$ \\
\hline $\begin{array}{l}\text { Low infestation } \\
\text { of pathogens } \\
\text { during dry season }\end{array}$ & $\begin{array}{l}(40 \\
(45.5)\end{array}$ & $\begin{array}{l}17 \\
(29.8)\end{array}$ & $22(36.1)$ & $34(42.5)$ & $22(20.8)$ & $\begin{array}{l}105 \\
(32.2)\end{array}$ \\
\hline $\begin{array}{l}\text { Mostly flat plane } \\
\text { topography }\end{array}$ & $\begin{array}{l}5 \\
(22.7)\end{array}$ & $\begin{array}{l}11 \\
(19.3)\end{array}$ & $16(26.2)$ & $20(25.0)$ & $21(19.8)$ & $\begin{array}{l}73 \\
(22.4)\end{array}$ \\
\hline
\end{tabular}

$\mathrm{N}$ is the number of respondents; values in parenthesis are the percentages of their respective frequencies

arc-like land mass lying to the immediate South of the Sahara Desert and stretching East-West across the breadth of the African continent. He further stated that the region stretches from Senegal on the Atlantic coast, through parts of Mauritania, Mali, Burkina Faso, Niger, Nigeria, Chad, and Sudan to Eritrea on the Red Sea coast. 
Almost all the respondents (92\%) were aware of the concept of climate change and its other attribute of global warming. Very high awareness level of climate change (88\%) was reported by Adebayo and Oruonye (2012) among farmers in Northern Taraba State.

The features that best describe Savannah and Sudano-Sahelian zones of Nigeria were presented in Table 3. Seasonal variation in availability of natural forage was reported by all the respondents interviewed in Sahel and Sudan zones. About $95 \%$ of the respondents in Northern Guinea Savannah zones corroborated the scarcity or non-availability of natural forages during the dry seasons. Life-threatening high temperature during dry season was also reported as $63.8 \%$ by 326 respondents. Low temperatures during Harmattan period were reported as 95.5\%, 80.7\%, 39.3\%, $22.5 \%$, and $17.0 \%$ by respondents from Sahel, Sudan, Northern Guinea Savannah, Southern Guinea Savannah, and Derived Savannah, respectively.

The Harmattan is a season in the West African subcontinent starting from November to mid-March. The season is highly dependent on air pressure variability in the Mediterranean area. The Harmattan period is dust laden and also characterized by low temperatures (Schwanghart and Schutt 2008). In Sahelian parts of Africa, Aeolian dust transport is made possible by several wind systems (Jäkel 2004; Engelstaedter et al. 2006). One of the wind system is Harmattan (Schwanghart and Schutt 2008).

Low precipitation was also reported in Table 3 . The proportions of the respondents that stated low precipitation as a prominent feature of the climate system were highest for Sahel (86.4\%) and lowest for Derived Savannah (21.7\%). This is an indication that there is more aridity in the Sahel and less in the Derived Savannah. Variability in Sahel rainfall is inextricably connected with the variability of the atmospheric circulation. Annual mean rainfall in the Sahel of Nigeria is less than $200 \mathrm{~mm}$ (Biasutti 2019). The author opined that across the zones, abundance or scarcity of rainfall and its distribution over the rainy season and the associated maximum temperature extremes determines the success or failure of farming system with its antecedent effects on livestock production. Desert encroachments were reported as a feature of Sahel (59.1\%) and Sudan (45.6\%) zones. Nigeria is faced with rapid desert encroachment affecting 15 states in the North. Most of the States covered in this chapter were described as desertification frontline States by Olagunju (2015).

\section{Livestock Population in Nigeria}

The total population of cattle in Nigeria was 20,407,607 in 2019 as against $20,231,589$ in 2018. The distribution of cattle in States within Nigeria was illustrated through Fig. 9. Zamfara tops the list of States with 3,432,486 heads of cattle. The goat population in Nigeria was totaled at 46,757,458 in 2019. The highest population of goats $(5,488,904)$ in 2019 was recorded in Katsina State (Fig. 10). Like as it is for cattle, Zamfara State tops the list of states for sheep production with the population size of 7,314,023 sheep (Fig. 11). These populations were reported in the Executive summary of Annual Performance Survey of National Agricultural Extension and Research Liaison Services in Nigeria (NAERLS 2019). 


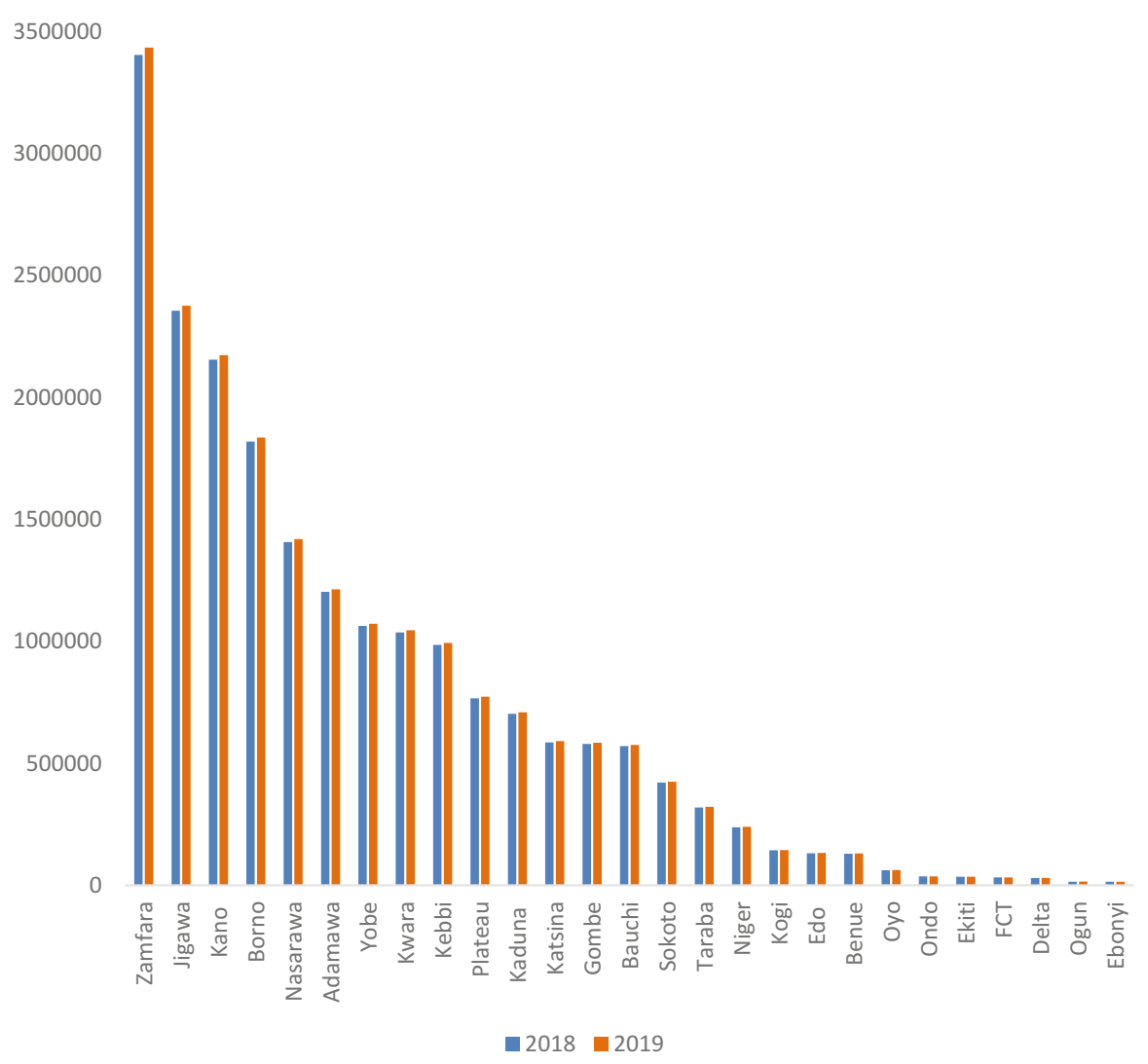

Fig. 9 Cattle population in Nigeria. (Source: Federal Department of Animal Production and Husbandry Services, FMARD, Abuja (Reported by NAERLS 2019))

The total populations of donkeys in Nigeria were 978,402 and 979,380 for 2018 and 2019, respectively (NAERLS 2019). The beast of burden (donkey), a very resilient animal is found mostly in about 11 states of the country (all within Sahel, Sudan, and Northern Guinea Savannah Zone of Nigeria) with the highest population found in Zamfara State $(331,641)$ in 2019. Other states with prominent populations of donkeys in 2019 were Sokoto $(153,657)$, Borno $(143,707)$, Kano $(135,962)$, Kebbi (82,870), Jigawa $(25,135)$, and Gombe $(14,241)$. Some other states like Bauchi and Yobe had populations of donkeys that are less than 1,500.

Camel is another livestock used as beast of burden in Nigeria. The total populations of camels in the country were 279,956 and 280,235 for 2018 and 2019, respectively. Almost half of all the camel population in Nigeria was found in Kano State with 128,104 heads of camel. Other states with some populations of camel in 2019 were Sokoto (60,346), Kebbi $(50,483)$, Jigawa $(12,851)$, Katsina $(9,581)$, Bauchi $(9,475)$, Niger $(3,270)$, and Yobe (501). It was of note that the rate of increase in population of camel and donkey is very negligible. These animals (camel and donkey) are reported to 


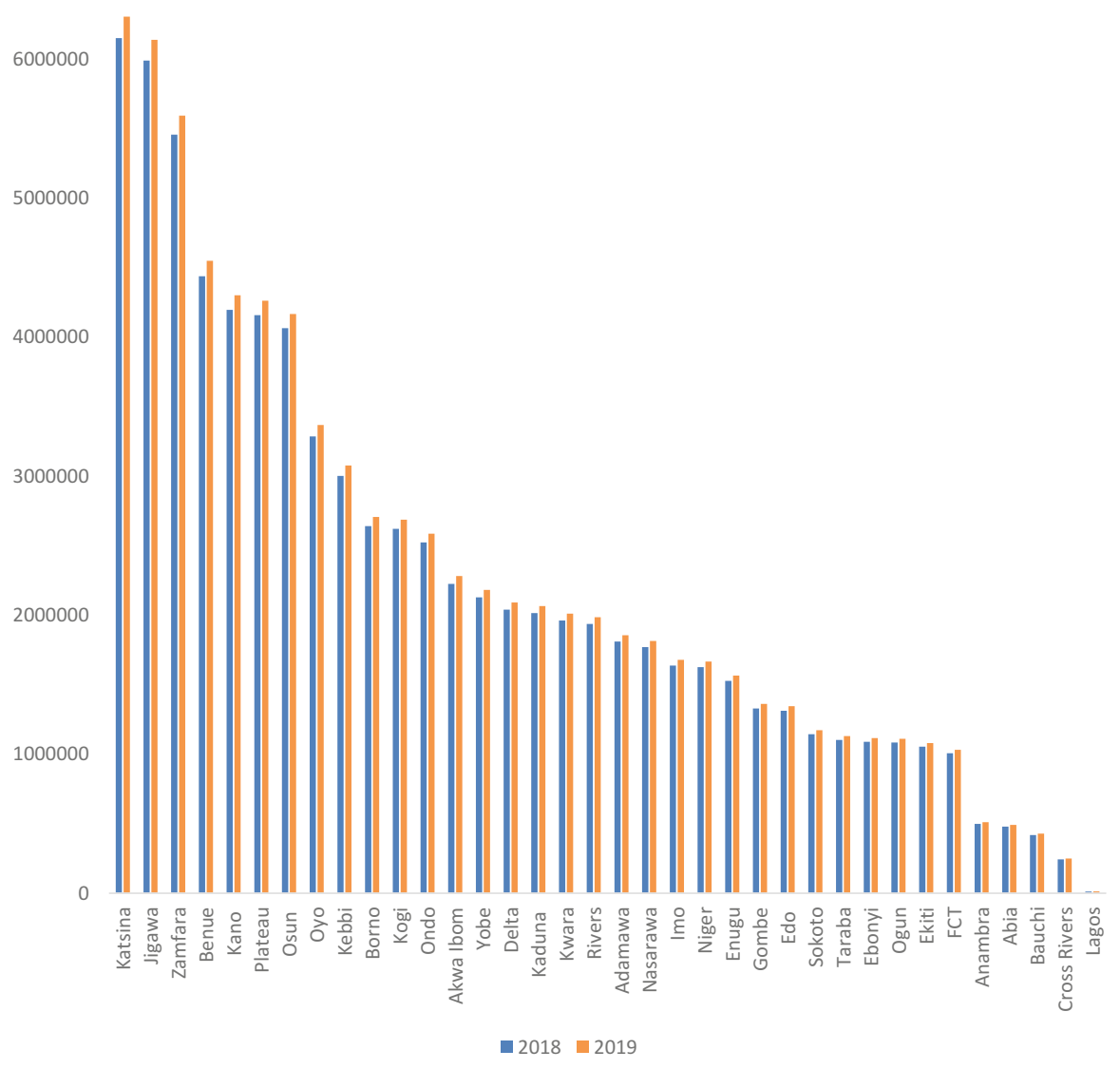

Fig. 10 Goat population in Nigeria. (Source: Federal Department of Animal Production and Husbandry Services, FMARD, Abuja (Reported by NAERLS 2019))

be dwindling in number as there is increased consumption and less production, therefore ways of increasing the population of this animal should be scientifically exploited to avoid the extinction of the species (Nelson et al. 2015).

The possible factors responsible for large population of livestock in the Savannah and Sudano - Sahelian zones of Nigeria were presented in Table 3. On the top of the list of such factors is the abundance of grasses, legumes, and other fodder crops as indicated by $59.8 \%$ of the respondents. Large expanse of grassland was also said to be a prominent factor enabling large population of livestock on the semiarid zone of Sahel, Sudan, and the Guinea Savannahs. Other factors being reported in favor of the large population of livestock in the zones being considered in this chapter were low infestation of pathogens during wet and dry seasons with $33.7 \%$ and $32.2 \%$, respectively. About $22 \%$ of the respondents stated that the flat plane topography in the zones might have contributed to the enormous populations of livestock being found in the zones. Lawal-Adebowale (2012) stated that the concentration of 


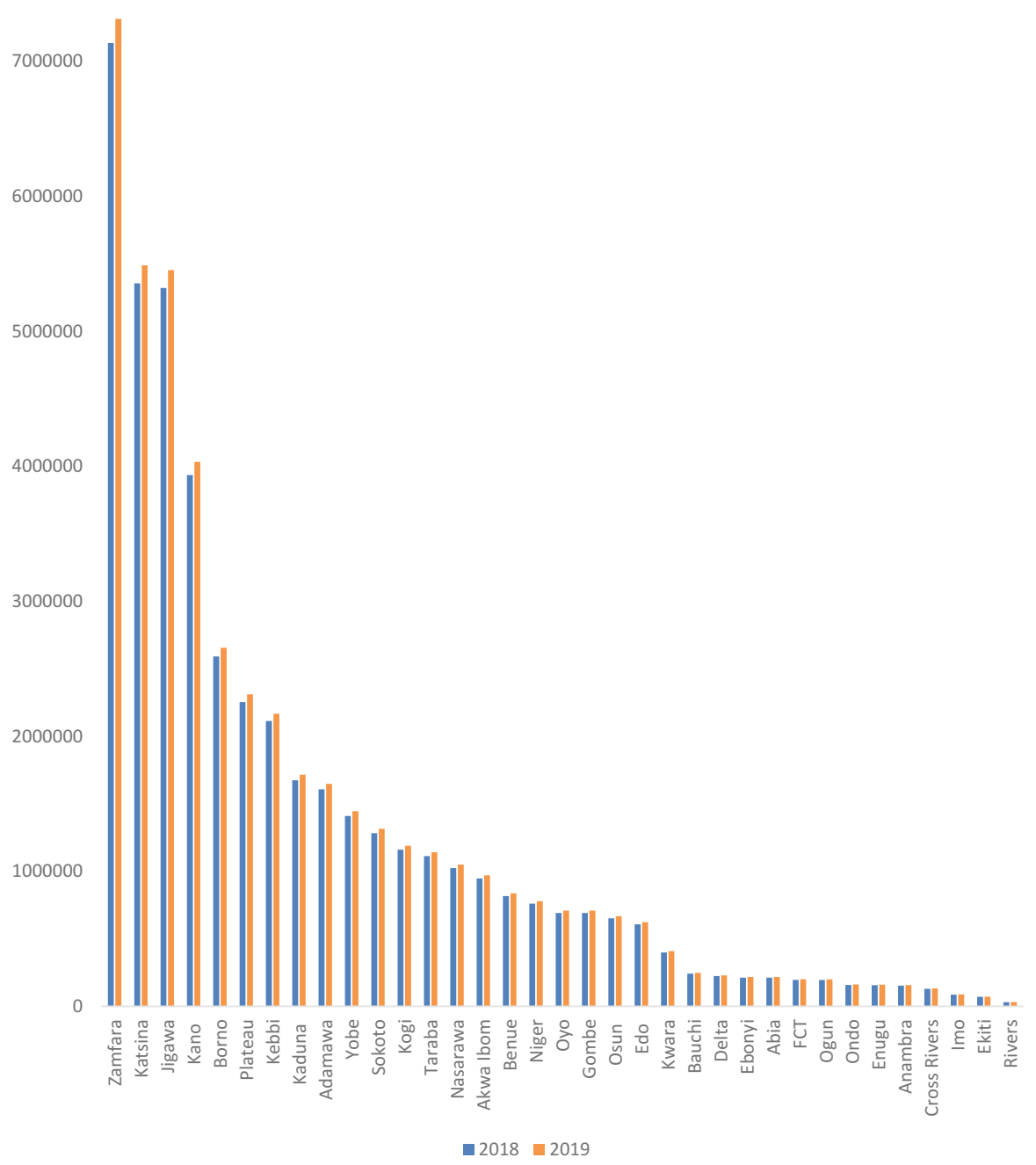

Fig. 11 Sheep population in Nigeria. (Source: Federal Department of Animal Production and Husbandry Services, FMARD, Abuja (Reported by NAERLS 2019))

Nigeria's livestock-base in the northern region is most likely to have been influenced by the ecological condition of the region which is characterized by low rainfall duration, lighter sandy soils, and longer dry season. This submission was predicated by the fact that drier tropics or semi-arid regions are more favorable to the ruminants. However, concerted efforts need to be made at retaining the large population of livestock in these regions (Savannah and Sudano-Sahelian) because livestock production will be possibly limited in the future by climate variability as animal's water consumption is expected to increase. There will be more demand for agricultural lands because of increase due to need for $70 \%$ growth in production, and food 
security concern since about one-third of the global cereal harvest will be needed for livestock feed (Rojas-Downing et al. 2017).

Table 4 showed the stakeholders perception of the effect of changes on climatic elements of livestock production in the Savannah and Sudano-Sahelian zone of Nigeria. About $77 \%$ of all the respondents agreed to the fact that changes in climatic

Table 4 Stakeholders' perception of effect of changes in climatic elements on livestock production in the Savannah and Sudano-Sahelian zones of Nigeria

\begin{tabular}{|c|c|c|c|c|c|c|}
\hline & $\begin{array}{l}\text { Sahel } \\
N=22\end{array}$ & $\begin{array}{l}\text { Sudan } \\
N=57\end{array}$ & $\begin{array}{l}\text { Northern } \\
\text { Guinea } \\
\text { Savannah } \\
N=61\end{array}$ & $\begin{array}{l}\text { Southern } \\
\text { Guinea } \\
\text { Savannah } \\
N=80\end{array}$ & $\begin{array}{l}\text { Derived } \\
\text { Savannah } \\
N=106\end{array}$ & $\begin{array}{l}\text { Total } \\
N=326\end{array}$ \\
\hline \multicolumn{7}{|c|}{ Changes in climatic elements affect livestock production in the zones } \\
\hline $\begin{array}{l}\text { Strongly } \\
\text { agree }\end{array}$ & $\begin{array}{l}10 \\
(45.5)\end{array}$ & $\begin{array}{l}11 \\
(19.3)\end{array}$ & $19(31.1)$ & $24(30.0)$ & $38(35.8)$ & \begin{tabular}{|l}
102 \\
$(31.3)$
\end{tabular} \\
\hline Agree & $\begin{array}{l}7 \\
(31.8)\end{array}$ & $\begin{array}{l}31 \\
(54.4)\end{array}$ & $23(37.7)$ & $45(56.2)$ & $42(39.6)$ & $\begin{array}{l}148 \\
(45.4)\end{array}$ \\
\hline Neutral & $0(0.0)$ & $4(7.0)$ & $8(13.1)$ & $4(0.5)$ & $9(8.5)$ & $25(7.7)$ \\
\hline Disagree & $1(4.5)$ & $4(7.0)$ & $2(3.3)$ & $2(2.5)$ & $4(3.8)$ & $13(4.0)$ \\
\hline $\begin{array}{l}\text { Strongly } \\
\text { disagree }\end{array}$ & $4(1.2)$ & $7(2.1)$ & $9(2.8)$ & $5(6.2)$ & $13(12.3)$ & \begin{tabular}{|l}
38 \\
$(11.7)$
\end{tabular} \\
\hline \multicolumn{7}{|c|}{ Perception about climatic elements that have the most variation in the zones } \\
\hline $\begin{array}{l}\text { Atmospheric } \\
\text { temperature }\end{array}$ & $\begin{array}{l}9 \\
(40.9)\end{array}$ & \begin{tabular}{|l}
31 \\
$(54.4)$
\end{tabular} & $33(54.1)$ & $41(51.2)$ & 49 (46.2) & \begin{tabular}{|l}
163 \\
$(50.0)$
\end{tabular} \\
\hline Rainfall & 10 & 21 & 19 & 28 & 42 & $\begin{array}{l}120 \\
(36.8)\end{array}$ \\
\hline $\begin{array}{l}\text { Sunshine } \\
\text { hour }\end{array}$ & $2(9.1)$ & $3(5.3)$ & $3(4.9)$ & $7(8.8)$ & $4(3.8)$ & $19(5.8)$ \\
\hline $\begin{array}{l}\text { Relative } \\
\text { humidity }\end{array}$ & $0(0.0)$ & $2(3.5)$ & $4(6.6)$ & $2(2.5)$ & $8(7.5)$ & $16(4.9)$ \\
\hline $\begin{array}{l}\text { Atmospheric } \\
\text { pressure }\end{array}$ & $1(4.5)$ & $0(0.0)$ & 1 (1.6) & $2(2.5)$ & $3(2.8)$ & $7(2.1)$ \\
\hline $\begin{array}{l}\text { Solar } \\
\text { radiation }\end{array}$ & $0(0.0)$ & $0(0.0)$ & $1(0.3)$ & $0(0.0)$ & $0(0.0)$ & $1(0.3)$ \\
\hline \multicolumn{7}{|c|}{$\begin{array}{l}\text { Perception about the climatic elements that are capable of affecting livestock productivity } \\
\text { when their variations are in the extreme }\end{array}$} \\
\hline $\begin{array}{l}\text { Atmospheric } \\
\text { temperature }\end{array}$ & $\begin{array}{l}17 \\
(77.3)\end{array}$ & $\begin{array}{l}39 \\
(68.4)\end{array}$ & 48 (78.7) & $54(67.5)$ & $69(65.1)$ & \begin{tabular}{|l|l|l}
227 \\
$(69.6)$
\end{tabular} \\
\hline $\begin{array}{l}\text { Relative } \\
\text { humidity }\end{array}$ & $2(9.1)$ & $\begin{array}{l}12 \\
(21.1)\end{array}$ & $14(23.0)$ & $17(21.3)$ & $35(33.0)$ & $\begin{array}{l}80 \\
(24.5)\end{array}$ \\
\hline $\begin{array}{l}\text { Solar } \\
\text { radiation }\end{array}$ & $\begin{array}{l}3 \\
(13.6)\end{array}$ & $\begin{array}{l}13 \\
(22.8)\end{array}$ & $9(14.8)$ & $15(18.8)$ & $18(20.0)$ & $\begin{array}{l}58 \\
(17.8)\end{array}$ \\
\hline $\begin{array}{l}\text { Sunshine } \\
\text { hours }\end{array}$ & $\begin{array}{l}4 \\
(18.2)\end{array}$ & $\begin{array}{l}7 \\
(12.3)\end{array}$ & $12(19.7)$ & $19(23.8)$ & $21(19.8)$ & $63(19.3$ \\
\hline $\begin{array}{l}\text { Greenhouse } \\
\text { gases }\end{array}$ & $2(9.1)$ & $4(7.0)$ & $9(14.8)$ & $4(5.0)$ & $7(6.6)$ & \begin{tabular}{|l|}
26 \\
$(10.0)$ \\
\end{tabular} \\
\hline
\end{tabular}

$\mathrm{N}$ is the number of respondents; values in parenthesis are the percentages of their respective frequencies 
elements affect livestock productivity. Kebede (2016) related the foremost reaction of animals under thermal weather as increase in respiration rate, rectal temperature, and heart rate. He further stated that the anticipated rise in temperature due to climate change is likely to aggravate the heat stress in livestock, adversely affecting their productive and reproductive performance and even death in extreme cases. The respondents observed that the climatic elements with most variations are atmospheric temperature $(50.0 \%)$, rainfall $(36.8 \%)$, and sunshine hour (5.8\%). The climatic element with the least variation as being reported by the respondents is solar radiation $(0.3 \%)$. Atmospheric temperature was also implicated by $69.9 \%$ of the respondents as a climatic element with the most debilitating effect on livestock when its variation is in the extreme. This was followed by relative humidity with $24.5 \%$ of the respondents stating that its effect can really affect livestock productivity.

\section{Adaptive Measures Against the Effect of Climate Change on Livestock Production}

Useable adaptive measures toward reducing the effects of climate change on livestock production are presented in Table 5 . About $55 \%$ of the respondents agreed that the use of adaptive measures in alleviating the effect of climate change on livestock is capable of reducing its debilitating effect on livestock. The rest of the respondents, about $45 \%$, were either neutral or disagreed with the fact that adaptive measures can mitigate the effect of climate change. It will be necessary to educate those that disagree on this very important fact. To guide the evolution of livestock production systems under the increase of temperature and extreme events, better information is needed regarding biophysical and social vulnerability, and this must be integrated with agriculture and livestock components (Nardone et al. 2010). The specific adaptive measures used by livestock farmers in the study locations are shown in Table 5 as well. At the top of the adaptive features of choice by respondents is provision of housing facilities for animals which was indicated by about $60 \%$ of the respondents. Provision of abundant water and supplements feeding were also indicated as adaptive measures by $45.4 \%$ and $44.2 \%$ of the respondents, respectively. Planting of tress to provide shades for livestock was of great interest because of the sustainable effect of this adaptive measure to livestock production. Trees are known to absorb carbon dioxide produced by man and animals that is apart from their primary function of shades as intended by livestock farmers. Development of superabsorbent fake leaves was proposed by scientists (Vince 2012) as a means of modulating the global temperature. This method was proposed as capable of removal of greenhouse gas from the atmosphere. The benefits of the introduction of artificial plants will be centered on geoengineering the planet which will be beyond its cooling effects.

Timely control of internal and external parasites was a choice of adaptive measure by a third of the respondents (31.3\%). This is expected to eliminate the stress on health status of the animals which will go a long way in stabilizing the internal physiological equilibrium of the animals. If properly done, the animals will have enough energy to 
Table 5 Useable adaptive measures toward reducing the effect of climate change on livestock production in Savannah and Sudano-Sahelian zones of Nigeria

\begin{tabular}{|c|c|c|c|c|c|c|}
\hline Feature & $\begin{array}{l}\text { Sahel } \\
N=22\end{array}$ & $\begin{array}{l}\text { Sudan } \\
N=57\end{array}$ & $\begin{array}{l}\text { Northern } \\
\text { Guinea } \\
\text { Savannah } \\
N=61\end{array}$ & $\begin{array}{l}\text { Southern } \\
\text { Guinea } \\
\text { Savannah } \\
N=80\end{array}$ & $\begin{array}{l}\text { Derived } \\
\text { Savannah } \\
N=106\end{array}$ & $\begin{array}{l}\text { Total } \\
N=326\end{array}$ \\
\hline
\end{tabular}

Stakeholders perceptions about reducing the effect of climate change on livestock production through the use of adaptive measures

\begin{tabular}{l|l|l|l|l|l|l}
\hline Strongly agree & $2(9.1)$ & $5(8.8)$ & $0(0.0)$ & $0(0.0)$ & $0(0.0)$ & $7(2.1)$ \\
\hline Agree & $\begin{array}{l}10 \\
(45.5)\end{array}$ & $\begin{array}{l}31 \\
(54.4)\end{array}$ & $28(45.9)$ & $45(56.3)$ & $58(54.7)$ & $\begin{array}{l}172 \\
(52.8)\end{array}$ \\
\hline Neutral & $4(18.2)$ & $6(10.5)$ & $3(4.9)$ & $6(7.5)$ & $5(4.7)$ & $24(7.4)$ \\
\hline Disagree & $0(0.0)$ & $4(7.0)$ & $1(1.6)$ & $0(0.0)$ & $5(4.7)$ & $10(3.1)$ \\
\hline Strongly disagree & $6(27.3)$ & $\begin{array}{l}11 \\
(19.3)\end{array}$ & $29(47.5)$ & $29(36.3)$ & $38(35.8)$ & $\begin{array}{l}113 \\
(34.7)\end{array}$ \\
\hline
\end{tabular}

\begin{tabular}{|c|c|c|c|c|c|c|}
\hline \multicolumn{7}{|c|}{ Adaptive measures used by livestock production stakeholders } \\
\hline $\begin{array}{l}\text { Provision of } \\
\text { housing for } \\
\text { animals }\end{array}$ & $\begin{array}{l}17 \\
(77.3)\end{array}$ & $\begin{array}{l}41 \\
(71.9)\end{array}$ & $35(57.4)$ & $51(63.8)$ & $50(47.2)$ & $\begin{array}{l}194 \\
(59.5)\end{array}$ \\
\hline $\begin{array}{l}\text { Frequent cleaning } \\
\text { of animal houses }\end{array}$ & $6(27.3)$ & $\begin{array}{l}17 \\
(29.8)\end{array}$ & $24(39.3)$ & $24(30.0)$ & $31(29.2)$ & $\begin{array}{l}102 \\
(31.3\end{array}$ \\
\hline $\begin{array}{l}\text { Provision of } \\
\text { supplement } \\
\text { feeding }\end{array}$ & $9(40.9)$ & $\begin{array}{l}31 \\
(54.4)\end{array}$ & $24(39.3)$ & $41(51.3$ & $39(36.8)$ & $\begin{array}{l}144 \\
(44.2)\end{array}$ \\
\hline $\begin{array}{l}\text { Provision of } \\
\text { water in } \\
\text { abundance }\end{array}$ & $\begin{array}{l}12 \\
(54.5)\end{array}$ & $\begin{array}{l}31 \\
(54.4)\end{array}$ & $27(44.3)$ & $38(47.5)$ & $39(36.8)$ & $\begin{array}{l}148 \\
(45.4)\end{array}$ \\
\hline $\begin{array}{l}\text { Timely control of } \\
\text { internal and } \\
\text { external parasites }\end{array}$ & $7(31.8)$ & $\begin{array}{l}17 \\
(29.8)\end{array}$ & $19(31.1)$ & $28(35.0)$ & $32(30.2)$ & $\begin{array}{l}103 \\
(31.6)\end{array}$ \\
\hline $\begin{array}{l}\text { Storage of excess } \\
\text { feed materials }\end{array}$ & $9(40.9)$ & $\begin{array}{l}18 \\
(31.6)\end{array}$ & $24(39.3)$ & $31(38.8)$ & $24(38.8)$ & $\begin{array}{l}106 \\
(32.5)\end{array}$ \\
\hline $\begin{array}{l}\text { Cultivation of } \\
\text { drought tolerant } \\
\text { varieties of forage } \\
\text { crops }\end{array}$ & $4(18.2)$ & $\begin{array}{l}18 \\
(31.6)\end{array}$ & $19(31.1)$ & $27(33.8)$ & $23(21.7)$ & $\begin{array}{l}91 \\
(27.9)\end{array}$ \\
\hline $\begin{array}{l}\text { Feeding of } \\
\text { livestock with } \\
\text { crop residues }\end{array}$ & $8(36.4)$ & $\begin{array}{l}16 \\
(28.1)\end{array}$ & $20(32.8)$ & $23(28.8)$ & $25(23.6)$ & $\begin{array}{l}92 \\
(28.2)\end{array}$ \\
\hline $\begin{array}{l}\text { Making of multi- } \\
\text { nutrient blocks }\end{array}$ & $3(13.6)$ & $8(14.0)$ & $10(16.4)$ & $14(17.5)$ & $13(12.3)$ & $\begin{array}{l}48 \\
(14.7) \\
\end{array}$ \\
\hline $\begin{array}{l}\text { Feeding of } \\
\text { livestock with } \\
\text { multi-nutrient } \\
\text { blocks }\end{array}$ & 7 (31.8) & $\begin{array}{l}10 \\
(17.5)\end{array}$ & 7 (11.5) & $12(15.0)$ & $11(10.4)$ & $\begin{array}{l}47 \\
(14.4)\end{array}$ \\
\hline $\begin{array}{l}\text { Seasonal } \\
\text { migration of } \\
\text { animals }\end{array}$ & 3 (13.6) & $2(3.5)$ & $12(19.7)$ & $6(7.5)$ & $17(16.0)$ & $\begin{array}{l}40 \\
(12.3)\end{array}$ \\
\hline
\end{tabular}


Table 5 (continued)

\begin{tabular}{|c|c|c|c|c|c|c|}
\hline Feature & $\begin{array}{l}\text { Sahel } \\
N=22\end{array}$ & $\begin{array}{l}\text { Sudan } \\
N=57\end{array}$ & $\begin{array}{l}\text { Northern } \\
\text { Guinea } \\
\text { Savannah } \\
N=61\end{array}$ & $\begin{array}{l}\text { Southern } \\
\text { Guinea } \\
\text { Savannah } \\
N=80\end{array}$ & $\begin{array}{l}\text { Derived } \\
\text { Savannah } \\
N=106\end{array}$ & $\begin{array}{l}\text { Total } \\
N=326\end{array}$ \\
\hline $\begin{array}{l}\text { Irrigation of } \\
\text { pasture during } \\
\text { dry season }\end{array}$ & $5(22.7)$ & $7(12.3)$ & $13(21.3)$ & $21(26.3)$ & $8(7.5)$ & $\begin{array}{l}54 \\
(16.6)\end{array}$ \\
\hline $\begin{array}{l}\text { Establishment of } \\
\text { ranch }\end{array}$ & $4(18.2)$ & $\begin{array}{l}12 \\
(21.1)\end{array}$ & $11(18.0)$ & $21(26.3)$ & 20 (18.9) & $\begin{array}{l}68 \\
(20.9)\end{array}$ \\
\hline $\begin{array}{l}\text { Planting of trees } \\
\text { to provide shades } \\
\text { for livestock }\end{array}$ & $11(50)$ & $\begin{array}{l}26 \\
(45.6)\end{array}$ & $29(47.5)$ & 37 (46.3) & $30(28.3)$ & $\begin{array}{l}133 \\
(40.8)\end{array}$ \\
\hline $\begin{array}{l}\text { Storage of crop } \\
\text { residues } \\
\text { obtainable during } \\
\text { crop harvest }\end{array}$ & $7(31.8)$ & $\begin{array}{l}14 \\
(24.6)\end{array}$ & $20(32.8)$ & $23(28.8)$ & $22(20.8)$ & $\begin{array}{l}86 \\
(26.4)\end{array}$ \\
\hline
\end{tabular}

$\mathrm{N}$ is the number of respondents; values in parenthesis are the percentages of their respective frequencies

combat stress from the environment. Storage of excess feed, especially during harvest, was stated as an adaptive measure by $32.5 \%$ of the respondents. This adaptive measure can be linked with another one that was also stated by the stakeholders, storage of crop residues obtainable during harvest $(26.4 \%)$. These two measures are some of the important components of crop-livestock integration systems as discussed by IyiolaTunji et al. (2015). Feeding livestock with crop residues in a well-planned basis on the nutrient requirements and biomass needs of these animals will ensure adequate usage of the crop residues. Establishment of ranch, irrigation of pasture during dry season, making of multi-nutrient blocks, feeding of livestock with multi-nutrient blocks and seasonal migration of animals were of the other adaptive measures being carried out to combat the effect of climate change as reported by substantial proportion of the respondents. Integrating livestock and crop production will serve as a form of conservation, which will enable shifting from the traditional systems which is focused exclusively on livestock or crop to a new approach which sustainably combines both. Agroforestry (establishing trees alongside crops and pastures in a mix) as a land management approach can help maintain the balance between agricultural production, environmental protection, and carbon sequestration to offset emissions from the sector. Agroforestry may increase productivity and improve quality of air, soil, and water, biodiversity, pests and diseases, and improves nutrient cycling (Jose 2009; Smith et al. 2012).

\section{Contribution of Livestock Production Activities Toward Climate Change}

Table 6 showed the contribution of livestock production activities toward climate change. A lot of the stakeholders interviewed (62.3\%) were aware of the 
Table 6 Contribution of livestock production activities toward climate change

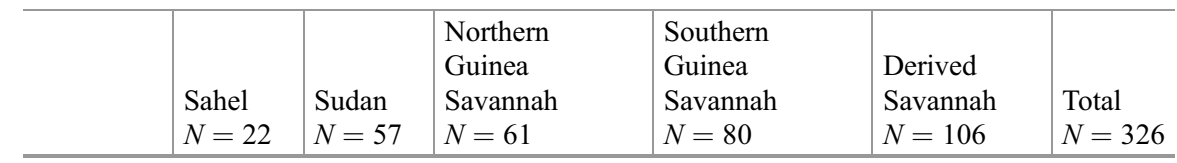

Stakeholder awareness of contribution of livestock production activities to changes in climate and global warming

\begin{tabular}{l|l|l|l|l|l|l}
\hline Yes & $\begin{array}{l}16 \\
(72.7)\end{array}$ & $\begin{array}{l}32 \\
(56.1)\end{array}$ & $43(70.5)$ & $44(55.0)$ & $68(64.2)$ & $\begin{array}{l}203 \\
(62.3)\end{array}$ \\
\hline No & $2(9.1)$ & $\begin{array}{l}11 \\
(19.3)\end{array}$ & $1(1.6)$ & $11(13.8)$ & $8(7.5)$ & $\begin{array}{l}33 \\
(10.1)\end{array}$ \\
\hline Maybe & $1(4.5)$ & $2(3.5)$ & $9(14.8)$ & $6(7.5)$ & $7(6.6)$ & $25(7.7)$ \\
\hline
\end{tabular}

Livestock generates substantial proportions of global greenhouse gas emission that are very bad for the environment

\begin{tabular}{l|l|l|l|l|l|l}
\hline Yes & $\begin{array}{l}14 \\
(63.6)\end{array}$ & $\begin{array}{l}28 \\
(49.1)\end{array}$ & $35(57.4)$ & $35(43.8)$ & $62(58.5)$ & $\begin{array}{l}174 \\
(53.4)\end{array}$ \\
\hline No & $\begin{array}{l}5 \\
(22.7)\end{array}$ & $\begin{array}{l}16 \\
(28.1)\end{array}$ & $11(18.0)$ & $33(41.3)$ & $24(22.6)$ & $\begin{array}{l}89 \\
(27.3)\end{array}$ \\
\hline Maybe & $\begin{array}{l}1 \\
(13.6)\end{array}$ & $\begin{array}{l}11 \\
(19.3)\end{array}$ & $15(24.6)$ & $12(15.0)$ & $19(17.9)$ & $\begin{array}{l}60 \\
(18.4)\end{array}$ \\
\hline
\end{tabular}

Livestock and their by-products account for several millions tons of carbon dioxide production per year

\begin{tabular}{l|l|l|l|l|l|l}
\hline Yes & $\begin{array}{l}12 \\
(54.5)\end{array}$ & $\begin{array}{l}22 \\
(38.6)\end{array}$ & $25(40.9)$ & $28(35.0)$ & $57(53.8)$ & $\begin{array}{l}114 \\
(35.0)\end{array}$ \\
\hline No & $\begin{array}{l}7 \\
(31.8)\end{array}$ & $\begin{array}{l}21 \\
(36.8)\end{array}$ & $13(21.3)$ & $27(33.8)$ & $25(23.6)$ & $\begin{array}{l}93 \\
(28.5)\end{array}$ \\
\hline Maybe & $\begin{array}{l}14 \\
(13.6)\end{array}$ & $\begin{array}{l}14 \\
(24.6)\end{array}$ & $23(37.7)$ & $25(31.3$ & $23(21.7)$ & $\begin{array}{l}88 \\
(27.0)\end{array}$ \\
\hline
\end{tabular}

Extensive system of livestock production plays a critical role in land degradation, climate change, water, and biodiversity loss

\begin{tabular}{l|l|l|l|l|l|l}
\hline Yes & $\begin{array}{l}14 \\
(63.6)\end{array}$ & $\begin{array}{l}29 \\
(5.1)\end{array}$ & $44(72.1)$ & $67(83.8)$ & $86(81.1)$ & $\begin{array}{l}240 \\
(73.6)\end{array}$ \\
\hline No & $2(9.1)$ & $\begin{array}{l}11 \\
(19.3)\end{array}$ & $5(8.2)$ & $6(7.5)$ & $6(5.7)$ & $30(9.2)$ \\
\hline Maybe & $\begin{array}{l}5 \\
(22.7)\end{array}$ & $\begin{array}{l}14 \\
(24.6)\end{array}$ & $9(14.8)$ & $7(8.8)$ & $14(13.2)$ & $\begin{array}{l}49 \\
(15.0)\end{array}$ \\
\hline
\end{tabular}

Economic, social, health, and environmental perspectives will be critical to solving the problems surrounding livestock production

\begin{tabular}{l|l|l|l|l|l|l}
\hline $\begin{array}{l}\text { Strongly } \\
\text { agree }\end{array}$ & $\begin{array}{l}6 \\
(27.3)\end{array}$ & $\begin{array}{l}18 \\
(31.6)\end{array}$ & $26(42.6)$ & $32(40.0)$ & $48(45.3)$ & $\begin{array}{l}130 \\
(39.9)\end{array}$ \\
\hline Agree & $\begin{array}{l}12 \\
(54.5)\end{array}$ & $\begin{array}{l}27 \\
(47.4)\end{array}$ & $29(47.5)$ & $41(51.3)$ & $47(44.3)$ & $\begin{array}{l}156 \\
(47.9)\end{array}$ \\
\hline Neutral & $\begin{array}{l}3 \\
(13.6)\end{array}$ & $5(8.8)$ & $0(0.0)$ & $5(6.3)$ & $7(6.6)$ & $20(6.1)$ \\
\hline Disagree & $0(0.0)$ & $5(8.8)$ & $5(8.2)$ & $2(2.5)$ & $4(3.8)$ & $16(4.9)$ \\
\hline $\begin{array}{l}\text { Strongly } \\
\text { disagree }\end{array}$ & $1(4.5)$ & $2(3.5)$ & $0(0.0)$ & $0(0.0)$ & $0(0.0)$ & $3(0.9)$ \\
\hline
\end{tabular}

$\mathrm{N}$ is the number of respondents; values in parenthesis are the percentages of their respective frequencies 
contribution of livestock production to climate change. Generations of substantial proportions of global greenhouse gases that are very bad for the environment were on the knowledge of more than half of the respondents (53.4\%). Just about the third (35\%) of the respondents were aware that livestock and their by-products account for several million tons of carbon dioxide production per year. Very large proportions (73.6\%) of respondents were aware that extensive system of livestock production plays a critical role in land degradation, climate change, water, and biodiversity loss. About $90 \%$ of the respondents however believed that economic, social, health, and environment perspectives are critical to solving the problems of the contributions of livestock production to climate change and global warning. In 2006, an FAO publication entitled "Livestock's long shadow - Environmental issues and options" indicated that the influence of livestock on the environment was much greater than it was considered. This provided detailed perspectives on the impact of livestock on water, biodiversity, and climate change. The issue on climate change and $18 \%$ estimated contribution of livestock to overall GHG emissions is the concern that attracted the most attention. The FAO (2006) estimated 18\% anthropogenic GHG emissions from livestock industry is disapproved by Goodland and Anhang (2009) who noted that the figure under-tallies emissions from certain production activities, underestimates demand, and absolutely omits some categories of emissions. They estimated that livestock production is contributing about $51 \%$ of anthropogenic GHG emissions. Goodland and Anhang (2009) revealed that $\mathrm{CO}_{2}$ from livestock respiration was ignored as a source of the GHGs from the FAO study (2006). Both manure and enteric fermentation contribute some $80 \%$ of methane emissions from agricultural activities and about $30-40 \%$ of the overall anthropogenic methane emissions (FAO 2006). The $62-89 \%$ of greenhouse emission recorded in this chapter was similar to the findings of FAO (2006). Similarly, there is an increasing awareness within the policy and research communities that fast growth in consumption and production of livestock commodities is contributing to variety of environmental problems. The main notable issue is livestock's significant contribution to anthropogenic emissions. Majority of the revenue is generated by pigs, chickens, sheep, goats, beef, and dairy cattle. These five species of livestock generate $92 \%$ of the overall revenue from livestock in Africa. In most rural communities, livestock is the only property of the poor, but it is highly susceptible to climate changes and extremes (Easterling and Aggarwal 2007; FAO 2007; Calvasa et al. 2009). The influence of climate change is anticipated to increase the susceptibility of livestock industry and reinforce current factors that are having impact on livestock farming systems (Gill and Smith 2008). The overall GHG emissions from livestock supply chains are approximately 7.1 gigatons $\mathrm{CO}_{2}$-equivalent annually for the 2005 reference point forming about $14.5 \%$ of all emissions induced by humans (IPCC 2007a). About $44 \%$ of the livestock industry emissions are in the form of $\mathrm{CH}_{4}$. Nitrous oxide and carbon dioxide represent $29 \%$ and $27 \%$, respectively. Livestock supply chains emit 9.2 gigatons $\mathrm{CO}_{2}$-eq of $\mathrm{CO}_{2}$ annually or $5 \%$ of anthropogenic $\mathrm{CO}_{2}$ emissions (IPCC 2007b). According to IPCC (2007b), 44\% of anthropogenic $\mathrm{CH}_{4}$ emissions or 3.1 gigatons $\mathrm{CO}_{2}$-eq of $\mathrm{CH}_{4}$ every year and $53 \%$ of anthropogenic $\mathrm{N}_{2} \mathrm{O}$ emissions or 2 gigatons $\mathrm{CO}_{2}$-eq of $\mathrm{N}_{2} \mathrm{O}$ are produced annually. Similar results were observed in 
this chapter, which reported that livestock products account for 88-93\% (Table 6) of the carbon dioxide production per year.

\section{Adaptive Measures Toward Mitigation of Effect of Climate Change on Livestock}

An adaptation such as the modification of production and management systems involves diversification of livestock animals and crops, integration of livestock systems with forestry and crop production, and changing the timing and locations of farm operations (IFAD 2010). Diversification of livestock and crop varieties can increase drought and heat wave tolerance, and may increase livestock production when animals are exposed to temperature and precipitation stresses. In addition, this diversity of crops and livestock animals is effective in fighting against climate change-related diseases and pest outbreaks (Kurukulasuriya and Rosenthal 2003; Batima et al. 2005; IFAD 2010). Changes in breeding strategies can help animals increase their tolerance to heat stress and diseases and improve their reproduction and growth development (Rowlinson et al. 2008; Henry et al. 2012). Adjusting animal diets can also be used as a mitigation measure, by changing the volume and composition of manure. GHG emissions can be reduced by balancing dietary proteins and feed supplements. If protein intake is reduced, the nitrogen excreted by animals can also be reduced. Supplements such as tannins are also known to have the potential to reduce emissions. Tannins are able to displace the nitrogen excretion from urine to feces to produce an overall reduction in emissions (Hess et al. 2006; Dickie et al. 2014). Some of the adaptable technologies for reducing the effect of livestock production activities on climate change and vice versa are also presented in Table 7 and discussions on each of them are presented below.

\section{Proper Livestock Health Management and Welfare}

On the top of the list of technologies as dictated by the respondents $(63.2 \%)$ is proper livestock health management and welfare. Reducing greenhouse gas (GHG) emissions may seem like extra work that can hurt business, but in reality, best management practices for reducing GHG emissions can be economical (Lindgren 2019). Animals that are maintained in optimum health conditions and given adequate welfare will have improved production efficiency and reduction of methane production from digestion of feeds.

\section{Adequate Waste Management and Utilization}

Almost equally important technology is adequate waste management and utilization as proposed by $59.2 \%$ of the respondents. The major contribution to greenhouse gas emissions is methane $\left(\mathrm{CH}_{4}\right)$ from ruminant animals through belching when the animals digest their feeds (Plate I). The other sources of the deleterious gases are from fecal waste excretion and storage. Adequate waste management and utilization is capable of reducing the quantity of the greenhouse gases 
Table 7 Adaptable technologies for reducing the effect of livestock production activities on climate change

\begin{tabular}{|c|c|c|c|c|c|c|}
\hline $\begin{array}{l}\text { Adaptable } \\
\text { technologies }\end{array}$ & $\begin{array}{l}\text { Sahel } \\
N=22\end{array}$ & $\begin{array}{l}\text { Sudan } \\
N=57\end{array}$ & $\begin{array}{l}\text { Northern } \\
\text { Guinea } \\
\text { Savannah } \\
N=61\end{array}$ & $\begin{array}{l}\text { Southern } \\
\text { Guinea } \\
\text { Savannah } \\
N=80\end{array}$ & $\begin{array}{l}\text { Derived } \\
\text { Savannah } \\
N=106\end{array}$ & $\begin{array}{l}\text { Total } \\
N=326\end{array}$ \\
\hline $\begin{array}{l}\text { Proper livestock } \\
\text { health } \\
\text { management } \\
\text { and welfare }\end{array}$ & $\begin{array}{l}13 \\
(59.1)\end{array}$ & $\begin{array}{l}40 \\
(70.2)\end{array}$ & $34(55.7)$ & $55(68.8)$ & $64(60.4)$ & $\begin{array}{l}206 \\
(63.2)\end{array}$ \\
\hline $\begin{array}{l}\text { Adequate waste } \\
\text { management } \\
\text { and utilization }\end{array}$ & $\begin{array}{l}13 \\
(59.1)\end{array}$ & $\begin{array}{l}32 \\
(56.1)\end{array}$ & $40(65.6)$ & $43(53.8)$ & $65(61.3)$ & $\begin{array}{l}193 \\
(59.2)\end{array}$ \\
\hline $\begin{array}{l}\text { Crop-livestock } \\
\text { integration } \\
\text { system }\end{array}$ & $9(40.9)$ & \begin{tabular}{|l|}
28 \\
$(49.1)$
\end{tabular} & $32(52.5)$ & $36(45.0)$ & $59(55.7)$ & $\begin{array}{l}164 \\
(50.3)\end{array}$ \\
\hline $\begin{array}{l}\text { Breeding for } \\
\text { more productive } \\
\text { animals }\end{array}$ & $\begin{array}{l}12 \\
(54.5)\end{array}$ & $\begin{array}{l}31 \\
(54.4)\end{array}$ & $28(45.9)$ & $43(53.8)$ & $49(46.2)$ & $\begin{array}{l}163 \\
(5.0)\end{array}$ \\
\hline $\begin{array}{l}\text { Use of methane } \\
\text { reducing feed } \\
\text { additives }\end{array}$ & $9(40.9)$ & $\begin{array}{l}21 \\
(36.8)\end{array}$ & $21(34.4)$ & $13(16.3)$ & $22(20.8)$ & $\begin{array}{l}86 \\
(26.4)\end{array}$ \\
\hline Ranching & $8(36.4)$ & $\begin{array}{l}15 \\
(26.3)\end{array}$ & $18(29.5)$ & $17(21.3)$ & $26(24.5)$ & $\begin{array}{l}84 \\
(25.8)\end{array}$ \\
\hline
\end{tabular}

$\mathrm{N}$ is the number of respondents; values in parenthesis are the percentages of their respective frequencies

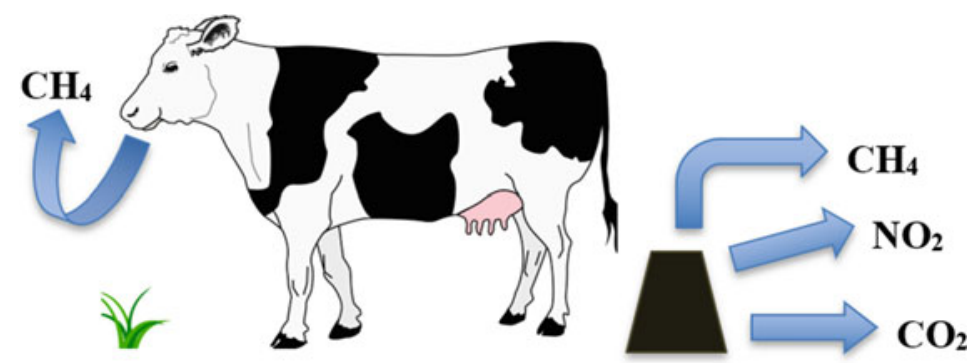

Plate I Greenhouse gas emissions from cattle production. (Source: Lindgren (2019))

emissions. Livestock farmers in the Sahel, Sudan, and the Guinea Savannah zones of Nigeria use the fecal waste as organic fertilizers for crop production. There were occasions where the litter materials from poultry production are fed to cattle (Lamidi 2005).

\section{Crop-Livestock Integration Systems}

A lot of the effect of livestock production on climate change can be eliminated if the farmers can engage in crop-livestock integration systems. About half of the respondents $(50.3 \%)$ agreed to this fact. Ickowicz et al. (2012) presented three variants of CLIS in 


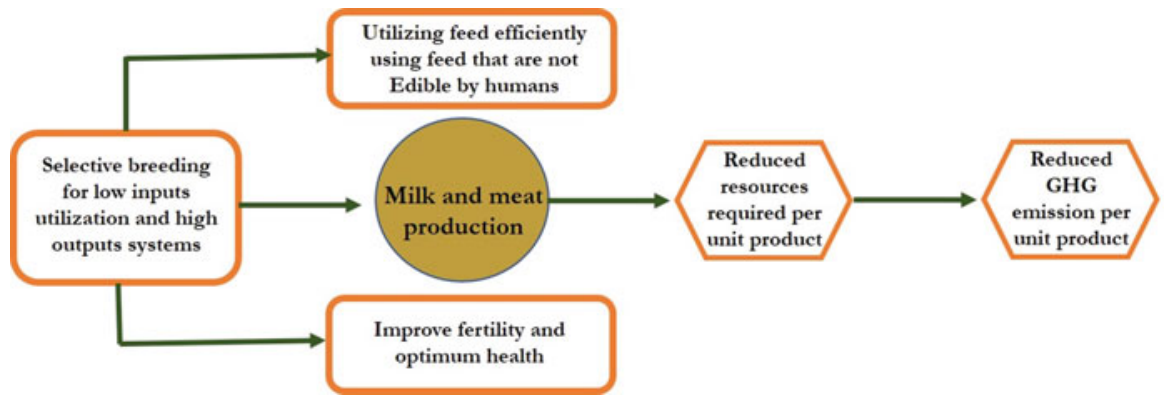

Fig. 12 Production efficiencies using management that can reduce GHG emissions beginning with selective breeding of a genotype for a particular system. (Adapted from Bell et al. (2012); modified by Iyiola-Tunji, A.O.) (C 2012 Bell MJ,. Eckard RJ, Pryce JE. Published in [short citation] under CC BY 3.0 license. Available from: http://dx.doi.org/10.5772/50395

arid and semiarid areas: (i) livestock only grazing systems, (ii) rainfed mixed croplivestock systems, and (iii) irrigated mixed crop-livestock systems. CLIS combine cereal crops (mainly millet, cowpea, sorghum, cotton and groundnut) and majorly ruminant animal production activities in different proportions. Crop-livestock integration systems (CLIS) enable recycling of products and wastes between crop production and livestock production. These methods are capable of increasing feed resources availability during the dry season and also replenish the soil for crop production through the use of fecal wastes from livestock. The major engagement of agropastoralists in Nigeria involves CLIS in a way though biomass inputs and outputs recycling are not scientifically calculated by the farmers (Iyiola-Tunji et al. 2017).

\section{Breeding for More Productive Animals}

Breeding for more productive animals was suggested by $50 \%$ of the respondents as an adaptive measure for reduction of greenhouse gas emissions. Selective breeding that is aimed at improving production efficiencies had been reported to result into increase productivity and gross efficiency by optimize the cost of production and reduce the number of animals that are needed to produce the same quantity of products (Bell et al. 2012). Reports from van de Haar and St. Pierr (2006) and Chagunda et al. (2009) related that more energy-efficient animals produce less waste in the form of methane and nitrogen excretion per unit product. The path toward reduced emission of greenhouse gases through selective breeding is depicted in Fig. 12. Animals that are selectively bred to utilize low inputs and give high outputs are expected to produce milk and meat (as the case may be) efficiently. The quantity of GHG emissions will be reduced once the number of animals put into productive is reduced.

\section{Use of Methane-Reducing Feed Additives}

The use of methane reducing feed additives was stated by $26.4 \%$ of the respondents as being capable of reducing the effect of livestock production activities on GHG 
emissions. Kataria (2015) observed that the practice of using feed additives to mitigate enteric methane production is more prominent in developed countries of the world where ruminant livestock are kept in well-managed production systems and generally fed diets that are very high in digestibility and nutrients. The results of this practice according to the author are an efficient production (milk or meat) relative to the amount of methane emitted. Klop (2016) expressed the advantage of using feed additives to mitigate GHG emissions as they are supplied in such amounts that the basal diet composition will not be largely affected by the feed additives (Klop 2016). Methane-reducing feed additives and supplements inhibit methanogens in the rumen, and subsequently reduce enteric methane emissions (Curnow 2019). Methane-reducing feed additives and supplements can be synthetic chemicals, natural supplements and compounds, such as tannins, and seaweed fats and oils (Curnow 2019). van Zijderveld et al. (2010) had experimented with lauric acid, myristic acid, linseed oil, and calcium fumarate as additives and obtained favorable results in the reduction of GHG emissions. Sunflower oil and monensin offer the greatest reductions in methane without substantial reductions in diet digestibility (Beauchemin and McGinn 2006). It is of note that the practice of using feed additives as an adaptive measure to reduce GHG emissions in developing countries like Nigeria is almost nonexistent.

\section{Ranching}

To further reduce livestock's greenhouse gas emissions while continuing to provide meat for a growing world population, beef cattle ranchers are proactively implementing methane-reducing methods to manage manure, improve soil health, and enhance herd efficiency. Ranching will enable farmers to consciously engage in practices that are capable of mitigating the effect of climate change on their livestock and also make attempt at GHG emissions from their livestock.

\section{Pathway of Responses}

The dual pathways of responses between climate change and livestock production activities are depicted in Fig. 13. Activities from livestock have very high tendencies to impact negatively on the environment and eventually causing unfavorable variability of climate and its elements, which is indicated by the blue big (fat) arrow that goes away from livestock to the environment and climate. The major component of the activities of livestock that is known to cause injury to the environment as depicted in Fig. 13 is the production of greenhouse gases (shown in an orange box on the right-hand side of the pathway). From the respondents in this study, some adaptive measures were stated as having controlling and mitigating effect at reducing the effect of activities of livestock on the climate and the environment. When these measures such as planting of trees to absorb $\mathrm{CO}_{2}$, adequate waste management and utilization, feeding of livestock with methane reducing feed additives, and breeding of animals with faster growth rate are effectively deployed, the destruction of the environment will be reduced. Key breeding traits associated with climate change 


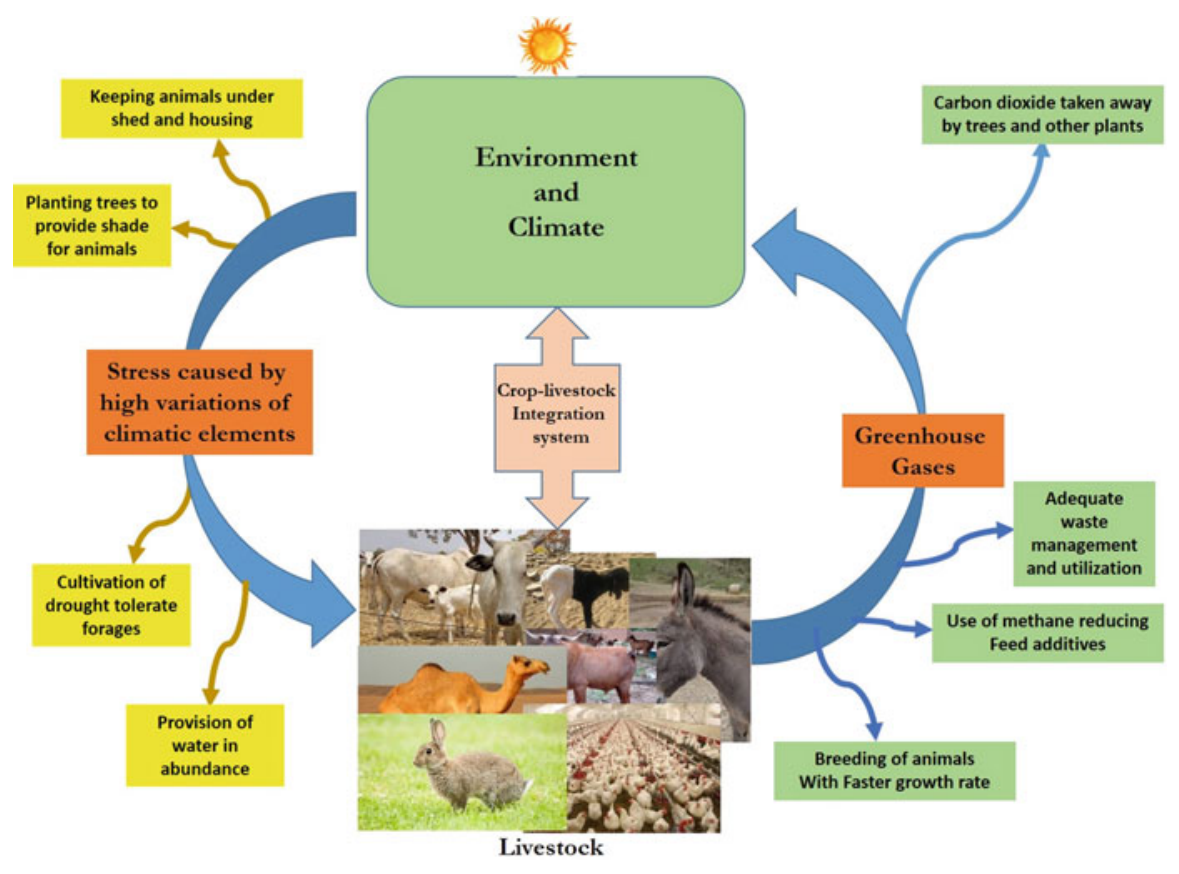

Fig. 13 Dual pathways of responses between climate and livestock

resilience and adaptation include thermal tolerance, low quality feed, high survival rate, disease resistance, good body condition, and animal morphology (Hoffmann 2008; Oseni and Bebe 2008). In general, developing countries have a weak capacity for high-tech breeding programs toward livestock improvement (IFAD 2002). Therefore, programs based on controlled mating methods are likely to be more appropriate. These programs usually do not produce immediate improvements. Improvements are usually not seen for at least one growing season, so a livestock producer must be able to incorporate long-term planning into production management strategies. Such measures could include:

- Identifying and strengthening local breeds that have adapted to local climatic stress and feed sources

- Improving local genetics through cross-breeding with heat and disease tolerant breeds

The environment and climate on the other side of the dual pathway is also known to induce stress on livestock. The respondents in this chapter stated that the components of the pathway that are in yellow boxes are capable of limiting the stress caused by high variations of climatic elements. The concept of crop-livestock integration system is advocated in this chapter as beneficial to livestock and environment in the short and long run. 


\section{Predicting Climatic Conditions Using Machine Learning Approach}

The ability to forecast climatic conditions is essential for proper planning in livestock production. Machine learning (ML) approach leverages on past data to predict future events. Three (3) ML model were built to predict the monthly minimum temperature, maximum temperature, and relatively respectively based on information from the previous 11 months.

The methodology adopted is to treat each prediction task as a supervised learning problem. This involves transforming the time series data (Fig. 14) into a featuretarget dataset using auto regressive (AR) technique.

The parameter (temp_min or temp_max or relative humidity) to be predicted is set as the target (dependent) variable and in each case be defined by

$$
T \min (t)|T \max (t)| R H(t)=f[T \min (t-n), T \max (t-n), R H(t-n)]
$$

$t$ is the prediction date.

$t-n$ denotes the time lags, $\mathrm{n}$ is an integer between 1 and 11

$T \min (t), T \max (t), R H(t)$ are temperatures and relative humidity to be predicted.

$T \min (t-n), T \max (t-n)$, and $R H(t-n)$ are minimum, maximum temperatures, and relative humidity, respectively, each time lag.

The transformation resulted in a dataset with 445 samples, each with 34 new features. In order to build an ML model, the samples were divided into 361 train
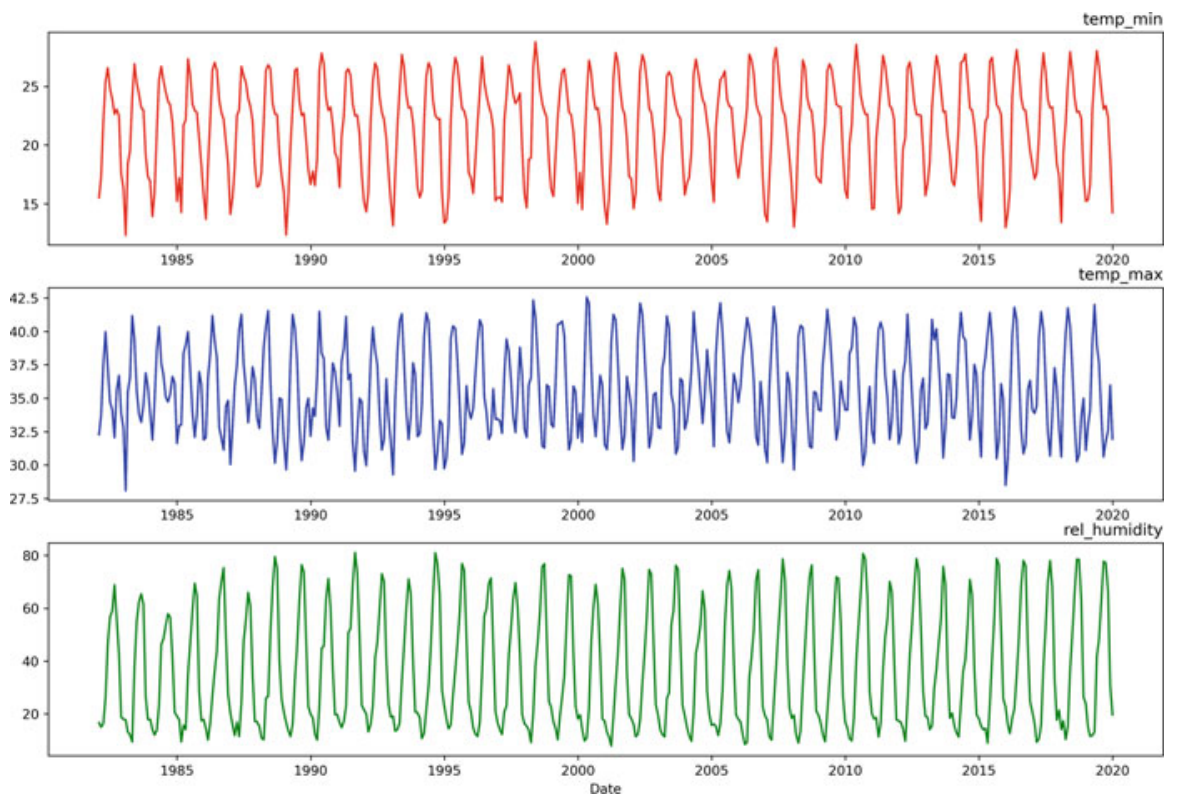

Fig. 14 Time Series of Temperature and Relative Humidity (1982-2019) 
(samples from 1982 to 2012) and 84 validations (samples from 2013 to 2019) sets. The Ensemble machine learning methods which are a stack of multiple learning algorithms were used to train our model. The choice of ensemble algorithm is to obtain better predictive performance than could be obtained from any of the constituent learning algorithms. For the three models that were built, the predictive accuracy measured by the $\mathrm{R}^{2}$ for minimum temperature, maximum temperature, and relative humidity are $0.9353,0.8772$, and 0.9569 respectively. The plots of the actual prediction and the ground truth for minimum and maximum temperatures and relative humidity are shown in Figs. 15, 16, and 17, respectively.

The usefulness of the model developed can be successfully used to predict minimum and maximum temperature as well as relative humidity of Ilela, Sokoto State (representative of Sahel ecoclimate zone). If these predictions are done appropriately, livestock farmers can use the predicted values to calculate temperature humidity index which is indication of level of stress to livestock. Farmers can in essence adjust their management practices accordingly to ensure adequate adaptation in reducing the anticipated stress that may come to their farm animals.

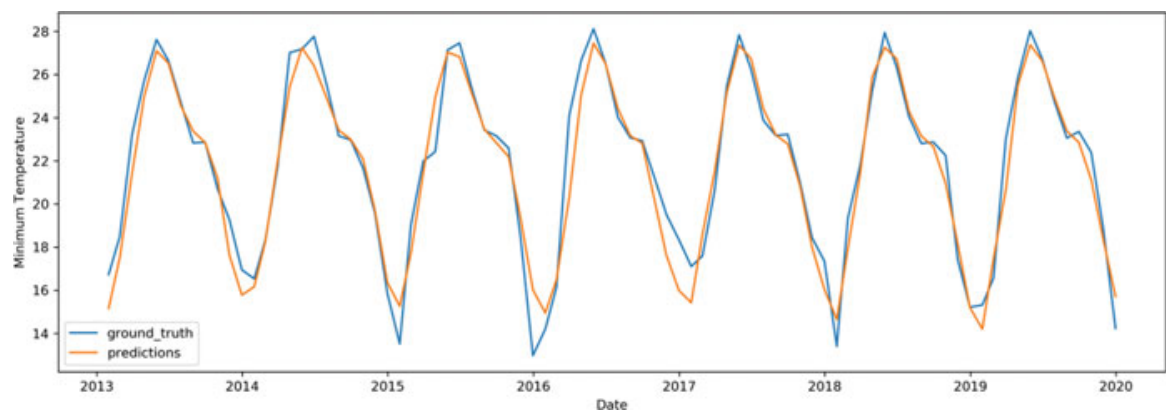

Fig. 15 Plot of predicted and actual values for minimum temperature for Sahel

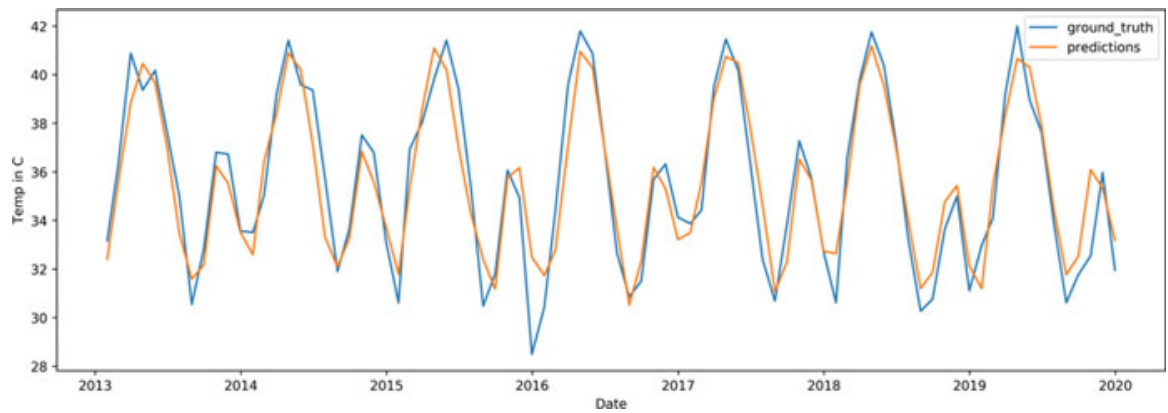

Fig. 16 Plot of predicted and actual values for maximum temperature for Sahel 


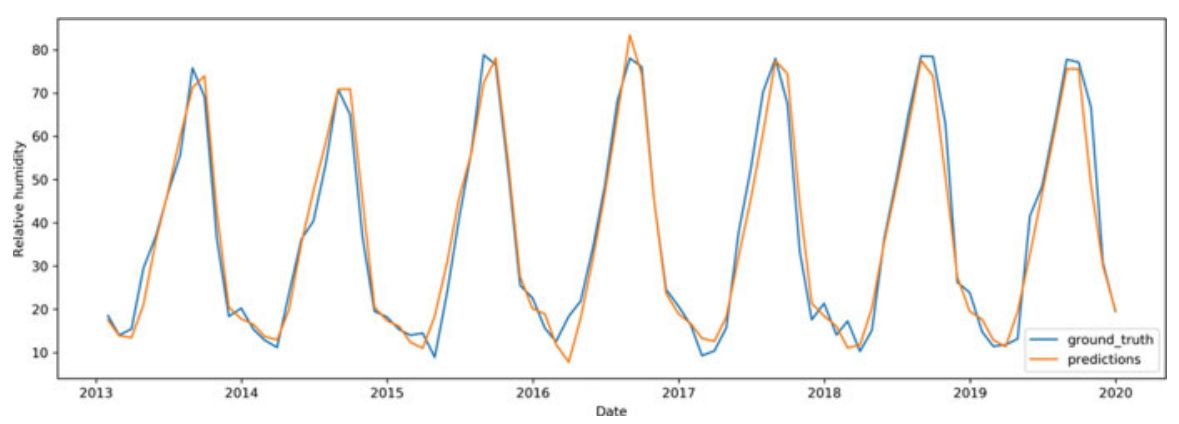

Fig. 17 Plot of predicted and actual values for relative humidity for Sahel

\section{Conclusion and Recommendations}

Large proportions of livestock stakeholders in Nigeria are aware of the effect of climate change on livestock production as well as the contributions of livestock production activities to climate change through GHG emissions. About $55 \%$ of the respondents agreed that the use of adaptive measures in alleviating the effect of climate change on livestock is capable of reducing its debilitating effect on livestock. The rest of the respondents, about $45 \%$, were either neutral or disagreed with the fact that adaptive measures can mitigate the effect of climate change. It will be necessary to educate those that disagree on this very important fact. About $90 \%$ of the respondents however believed that economic, social, health, and environment perspectives are critical to solving the problems of the contributions of livestock production to climate change and global warning. Based on the predictive model developed for temperature and relative humidity in a sample location (Ilela) using Machine Learning in this chapter, there is need for development of a web or standalone application that will be useable by Nigerian farmers, meteorological agencies, and extension organizations as climate fluctuation early warning system. Development of this predictive model needs to be expanded and made functional.

\section{References}

AbdulKadir A, Usman MT, Shaba AH (2015) An integrated approach to delineation of the ecoclimatic zones in Northern Nigeria. J Ecol Nat Environ 7(9):247-255

Adebayo AA, Oruonye ED (2012) An assessment of the level of farmers awareness and adaptation to climate change in Northern Taraba State, Nigeria. In: Proceedings of the 2012 climate change and ICT conference by Centre for Climate Change and Environmental Research, Osun State University, Osogbo

Adegoke J, Lamptey BL (1999) Intra seasonal variability of summertime precipitation in the Guinea Coastal Region of West Africa'. Paper presented at Cheikh Anta Diop University, Dakar, Senegal, June 1999 
Adesogan AT, Havelaar AH, Mckune SL, Eilitta M, Dahl GE (2020) Animal source foods: Sustainability problem or malnutrition and sustainability solution? Perspective matters. Glob Food Secur 25:1-7

Akande A, Costa AC, Mateu J, Henriques R (2017) Geospatial analysis of extreme weather events in Nigeria (1985-2015) using self-organizing maps. Adv Meteorol 2017:11, Article ID 8576150. https://doi.org/10.1155/2017/8576150

Aydinalp C, Cresser MS (2008) The effects of global climate change on agriculture. Am Eurasian J Agric Environ Sci 3(5):672-676

Ayoade JO (2008) Techniques in climatology. Stirling-Horden Publishers Ltd, Ibadan, pp 42-118

Batima P, Bat B, Tserendash L, Bayarbaatar S, Shiirev-Adya S, Tuvaansuren G, Natsagdorj L, Chuluun T (2005) Adaptation to climate change, vol 90. Admon Publishing, Ulaanbaatar

Beauchemin KA, McGinn SM (2006) Effects of various feed additives on the methane emissions from beef cattle. Int Congr Ser 1293:152-155. https://doi.org/10.1016/j.ics.2006.01.042

Bell MJ, Eckard RJ, Pryce JE (2012) Breeding dairy cows to reduce greenhouse gas emissions, livestock production, Khalid Javed, IntechOpen. https://doi.org/10.5772/50395 https://www. intechopen.com/books/livestock-production/breeding-dairy-cows-to-reduce-greenhouse-gasemissions. Accessed 25 Sept 2020.

Berihulay H, Abied A, He X, Jiang L, Ma Y (2019) Adaptation mechanisms of small ruminants to environmental heat stress. Animals 9:75

Bettencourt EMV, Tilman M, Narciso V, Carvalho MLS, Henriques PDS (2015) The livestock roles in the wellbeing of rural communities of Timor-Leste. Braz J Rural Econ Soc 53(1):S063-S080

Biasutti M (2019) Rainfall trends in the African Sahel: characteristics, processes, and causes. WIREs Clim Change 10:e591. https://doi.org/10.1002/wcc.591

Brown S (2019) How livestock farming affects the environment. https://www.downtoearth.org.in/ factsheet/how-livestock-farming-affects-the-environment-64218. Accessed 10 July 2020

Calvasa C, Chuluunbaatar D, Fara K (2009) Livestock thematic papers- tools for project design. International Fund for Agricultural Development (IFAD) publication. Retrieved from www.ifad. org//rkm/factsheet/cc.pdf. Accessed 10 Dec 2015

Chagunda MGG, Römer DAM, Roberts DJ (2009) Effect of genotype and feeding regime on enteric methane, non-milk nitrogen and performance of dairy cows during the winter feeding period. Livest Sci 122:323-332

Curnow M (2019) Carbon farming: reducing methane emissions from cattle using feed additives. https://www.agric.wa.gov.au/climate-change/carbon-farming-reducing-methane-emissions-cat tle-using-feed-additives. Accessed 25 Sept 2020

Dickie A, Streck C, Roe S, Zurek M, Haupt F, Dolginow A (2014) Strategies for mitigating climate change in agriculture: abridged report. Climate focus and california environmental associates, prifadred with the support of the climate and land use Alliance. Report and supplementary materials available at www.agriculturalmitigation.org

Downing TE, Ringuis L, Hulme M, Waughray D (1997) Adapting to climate change in Africa. Mitig Adapt Strat Glob Chang 2:19

Easterling WE, Aggarwal PK (2007) Food, fibre and forest products. In: Parry ML, Canziani OF, Palutikof JP, Van der Linden PJ, Hanson CE (eds) Climate change 2007- impacts, adaptation and vulnerability. Contribution of working group II to the fourth assessment report of the intergovernmental panel on climate change. Cambridge University Press, Cambridge, pp 273-313

Edwards DC, McKee TB (1997) Characteristics of 20th century drought in the United States at multiple time scales. Climatology report no. 97-2, Colorado State University Ft. Collins

Engelstaedter S, Tegen I, Washington R (2006) North African dust emissions and transport. Earth Sci Rev 79:73-100

FAO (1993) Livestock and improvement of pasture, feed and forage. FAO committee on agriculture, 12th session, item 7, 26 April to 4 May 1993, Rome, 19 pp 
FAO (2006) In: Steinfeld H, Gerber P J, Wassenaar T, Castel V, Rosales M, de Haan C (eds) Livestock's long shadow - environmental issues and options Food and Agriculture Organization of the United Nations, Rome

FAO (2007) Adaptation to climate change in agriculture, forestry, and fisheries: perspective, framework and priorities. FAO, Rome

FAO (2011) Mapping supply and demand for animal-source foods to 2030, by Robinson TP, Pozzi F. Animal production and health working paper no. 2, Rome

Flachowsky G, Kamphues J (2012) Carbon footprints for food of animal origin: what are the most preferable criteria to measure animal yield? Animals (Basel) 2(2):108-126

Gill M, Smith P (2008) Mitigating climate change: the role of livestock in agriculture. In: Livestock and global change conference proceeding. May 2008, Tunisia

Goodland R, Anhang J (2009) Livestock and climate change. What if the key actors in cli-mate change were pigs, chickens and cows? Worldwatch November/December 2009, Worldwatch Institute, Washington, DC, pp 10-19

Hahn GL (1989) Bioclimatology and livestock housing: theoretical and applied aspects. In: Proccedings of Brazilian workshop on animal bioclimatology. Jaboticabal, p 15

Haider H (2019) Climate change in Nigeria: impacts and responses. K4D (Knowledge, evidence and learning for development) Helpdesk report. https://assets.publishing.service.gov.uk/media/ 5dcd7a1aed915d0719bf4542/675_Climate_Change_in_Nigeria.pdf

Henry B, Charmley E, Eckard R, Gaughan JB, Hegarty R (2012) Livestock production in a changing climate: adaptation and mitigation research in Australia. Crop Pasture Sci 63:191-202

Hess HD, Tiemann TT, Noto F, Carulla JE, Kreuzer M (2006) Strategic use of tannins as means to limit methane emission from ruminant livestock. In: International conference on Greenhouse gases and animal agriculture, vol. 129, Elsevier International congress series, Zurich, Switzerland, pp 164-167

Hoffmann I (2008) Livestock genetic diversity and climate change adaptation. Livestock and global change conference proceeding. May 2008, Tunisia

Ickowicz A, Ancey V, Corniaux C, Duteurtre G, Poccard-Chappuis R, Touré I, Vall E, Wane A (2012) Crop-livestock production systems in the Sahel- increasing resilience for adaptation to climate change and preserving food security. Building resilience for adaptation to climate change in the agriculture sector. In: Proceedings of a joint FAO/OECD workshop (eds: Meybeck A, Lankoski J, Redfern S, Azzu N, Gitz V). http://www.fao.org/3/i3084e/i3084e.pdf

IFAD (International Fund for Agricultural Development) (2010) Livestock and climate change. http://www.ifad.org/lrkm/events/cops/papers/climate.pdf

IFAD (The International Fund for Agricultural Development) (2002) 'The rural poor' in world poverty report. IFAD, Rome

IPCC (2007a) Summary for policymakers. In: Climate change 2007: impacts, adaptation and vulnerability. Contribution of working group II to the fourth assessment report of the Intergovernmental Panel on Climate Change: Parry ML, Canziani OF, Palutikof JP, Van der Linden PJ, Hanson CE. Cambridge University Press, 1000

IPCC (2007b) Climate change 2007: mitigation. In: Metz B, Davidson O R, Bosch P R, Dave R and Meyer LA (eds) Contribution of working group III to the fourth assessment report of the intergovernmental panel on climate change. Cambridge University Press, Cambridge, UK/ New York

Iyiola-Tunji AO (2012) Genetic analysis of growth rate and some reproductive traits of Balami, Uda and Yankasa sheep and their crosses. Unpublished $\mathrm{PhD}$ thesis submitted to School of Post Graduate Studies, Ahmadu Bello University, Zaria, Nigeria

Iyiola-Tunji AO, Annatte I, Adesina MA, Ojo OA, Buba W, Nuhu S, Bello M, Saleh I, Yusuf AM, Tukur AM, Hussaini AT, Aguiri AO (2015) Evaluation of crop-livestock integration systems 
among rural farm families at adopted villages of National Agricultural Extension and Research Liaison Services. J Agric Ext 19(2):46-58

Iyiola-Tunji AO, Adesina MA, Ojo OA, Buba W, Saleh I, Yusuf AM, Tukur AM, Bello M, Nuhu S (2017) Characterization of labour usage, harvest and processing activities among crop and livestock farming households at NAERLS-adopted villages. Nig J Agric Ext 18 (1):51-70

Jäkel D (2004) Observations on the dynamics and causes of sand and dust storms in arid regions, reported from North Africa and China. Erde 135:341-367

Jose S (2009) Agroforestry for ecosystem services and environmental benefits: an overview. Agrofor Syst 76:1-10

Kataria RP (2015) Use of feed additives for reducing greenhouse gas emissions from dairy farms. Microbiol Res 6(6120):19-25

Kebede D (2016) Impact of climate change on livestock productive and reproductive performance. Livest Res Rural Dev 28(2). http://www.lrrd.org/lrrd28/12/kebe28227.htm

Kebede A, Tamiru Y, Haile G (2018) Review on impact of climate change on animal production and expansion of animal diseases. Scholars J Agric Vet Serv 5(4):205-215

Khalifa HH (2003) Bioclimatology and adaptation of farm animals in a changing climate. In: Interactions between climate and animal production, European federation of animal science technical series, vol 7. Wageningen Academic Publishers, Wageningen, pp 15-29

Klop G (2016) Low emission feed - using feed additives to decrease methane production in dairy cows. PhD thesis, Wageningen University, Wageningen, NL. 168 pages. ISBN 978-94-6257894-4. https://doi.org/10.18174/387944

Kurukulasuriya P, Rosenthal S (2003) Climate change and agriculture: a review of impacts and adaptations. Climate Change series paper no. 91, World Bank, Washington DC

Lamidi OS (2005) The use of some non-conventional protein sources for fattening cattle. Unpublished PhD thesis submitted to the School of Post Graduate Studies, Ahmadu Bello University, Zaria

Lawal-Adebowale OA (2012) Dynamics of ruminant livestock management in the context of the Nigerian Agricultural System. Livestock production chapter 4. Intech. pp 62-80. https://doi.org/ $10.5772 / 52923$

Lindgren J (2019) Reducing Greenhouse gas emissions from cattle production. Friday, October 4, 2019. https://water.unl.edu/article/animal-manure-management/reducing-greenhouse-gas-emis sions-cattle-production

McClanahan TR, Cinner JE, Maina J, Graham NAJ, Daw TM, Stead SM, Wamukota A, Brown K, Ateweberhan M, Venus V, Polunin NVC (2008) Conservation action in a changing climate. J Soc Conserv Biol 1(2):53-59

Murphy SP, Allen LH (2003) Nutritional importance of animal source foods. J Nutr 133 (11):3932S-3935S

Myhre G, Samset BH, Schulz M, Balkanski Y, Bauer S, Berntsen TK, Bian H, Bellouin N, Chin M, Diehl T, Easter RC, Feichter J, Ghan SJ, Hauglustaine D, Iversen T, Kinne S, Kirkevåg A, Lamarque J-F, Lin G, Liu X, Lund MT, Luo G, Ma X, van Noije T, Penner JE, Rasch PJ, Ruiz A, Seland Ø, Skeie RB, Stier P, Takemura T, Tsigaridis K, Wang P, Wang Z, Xu L, Yu H, Yu F, Yoon J-H, Zhang K, Zhang H, Zhou C (2013) Radiative forcing of the direct aerosol effect from AeroCom Phase II simulations. Atmos Chem Phys 13:1853-1877

NAERLS (2019) https://naerls.gov.ng/wp-content/uploads/2020/03/Agricultural-Performance-Sur vey-of-2019-Wet-Season-in-Nigeria-Executive-Summary.pdf

Nardone A, Ronchi B, Lacetera N, Ranieri MS, Bernabucci U (2010) Effect of climate change on animal production and sustainability of livestock system. Livest Sci 130:57-69

Nelson KS, Bwala DA, Nuhu EJ (2015) The Dromdry camel: a review on the aspects of history, physical description, adaptations, behaviour/lifecycle, diet, reproduction, uses, genetics and diseases. Niger Vet J 36(4):1299-1317 
Nicholson SE, Palao IM (1993) A re-evaluation of rainfall variability in the Sahel. Part I. Characteristics of rainfall fluctuations. Int J Climatol 13(4):371-389

Nwosu CC, Ogbu CC (2011) Climate change and livestock production in Nigeria: issues and concerns. Agro Sci J Trop Agric Food Environ Ext 10(1):41-60

Ojo O (1977) The climate of West Africa. Heineman, London

Olagunju TE (2015) Drought, desertification and the Nigerian environment: a review. J Ecol Nat Environ 7(7):196-209

Onah NG, Alphonsus NA, Ekenedilichukwu E (2016) Mitigating climate change in Nigeria: African traditional religious values in focus. Mediterr J Soc Sci 7(6):299-308. https://doi.org/ 10.5901/mjss.2016.v7n6p299

Oseni S, Bebe O (2008) Climate change, genetics of adaptation and livestock production in lowinput systems. Paper presented at ICID+18 2nd international conference: climate, sustainability and development in semi-arid regions August 16-20, 2010, Fortaleza-Ceará, Brazil and Hoffmann I (2008) Livestock genetic diversity and climate change adaptation. Livestock and global change conference proceeding. May 2008, Tunisia

Riahi K, Rao S, Krey V, Cho C, Chirkov V, Fisher G, Kindermann G, Nakicenovic N, Rafaj P (2011) RCP 8.5 - a scenario of comparatively high greenhouse gas emissions. Climate Change 109:33-57

Rojas-Downing MM, Nejadhashemi AP, Harrigan T, Woznicki SA (2017) Climate change and livestock: impacts, adaptation and mitigation. Clim Risk Manag 16:133-144

Rowlinson P, Steele M, Nefzaoui A (2008) Livestock and global climate change: adaptation I and II. In: Rowlinson P, Steel M, Nefzaoui A (eds) Livestock and global climate change conference proceeding. Cambridge University Press, Tunisia, pp 56-85

Schmidt MI (2008) The relationship between cattle and savings: a cattle-owner perspective. Dev South Afr 9(4):433-444

Schwanghart W, Schutt B (2008) Meterological causes of Harmattan dust in West Africa. Geomorphology 95:412-428

Smith JP, Pearce BD, Wolfe MS (2012) Reconciling productivity with protection of the environment: is temperate agroforestry the answer? Renewable Agric Food Syst 28(1):80-92

Srivastava NSL (2006) Farm power sources, their availability and future requirement to sustain agricultural production status of farm mechanization in India. IASRI report, 57-68

Suleiman M (2017) Sahel region, Africa. The Conversation Newsletter. https://theconversation. com/sahel-region-africa-72569

Thomson AM, Calvin KV, Smith SJ, Kyle GP, Volke A, Patel P, Delgado-Arias S, BondLamberty B, Wise MA, Clarke LE, Edmonds JA (2011) RCP4.5: a pathway for stabilization of radiative forcing by 2100 . Clim Chang 109(1-2):77-94. https://doi.org/10.1007/s10584011-0151-4

Umar MA, Dalhatu M, Bello A, Nawawi H (2013) Animal traction as source of farm power in rural areas of Sokoto State, Nigeria. Health Safety Environ 1(1):23-28

Umunna MO, Olafadehan OA, Arowona A (2014) Small ruminant production and management systems in Urban area of Southern Guinea Savannah of Nigeria. Asian J Agric Food Sci 2(2):107-114

van de Haar MJ, St. Pierre N (2006) Major advances in nutrition: relevance to the sustainability of the dairy industry. J Dairy Sci 89(4):1280-1291

van Vuuren DP, Edmonds J, Kainuma M et al (2011) The representative concentration pathways: an overview. Clim Chang 109:5-31. https://doi.org/10.1007/s10584-011-0148-Z

van Zijderveld SM, Fonken B, Dijkstra J, Gerrits WJJ, Perdok HB, Fokkink W, Newbold JR (2010) Effects of a combination of feed additives on methane production, diet digestibility, and animal performance in lactating dairy cows. J Dairy Sci 94:1445-1454. https://doi.org/10.3168/jds. 2010-3635

Vince $\mathrm{G}$ (2012) Sucking $\mathrm{CO}_{2}$ from the skies with artificial trees. Future. BBC Program 4th October, 2012. https://www.bbc.com/future/article/20121004-fake-trees-to-clean-the-skies 
Open Access This chapter is licensed under the terms of the Creative Commons Attribution 4.0 International License (http://creativecommons.org/licenses/by/4.0/), which permits use, sharing, adaptation, distribution and reproduction in any medium or format, as long as you give appropriate credit to the original author(s) and the source, provide a link to the Creative Commons license and indicate if changes were made.

The images or other third party material in this chapter are included in the chapter's Creative Commons license, unless indicated otherwise in a credit line to the material. If material is not included in the chapter's Creative Commons license and your intended use is not permitted by statutory regulation or exceeds the permitted use, you will need to obtain permission directly from the copyright holder.

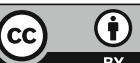

